University of Louisville

ThinkIR: The University of Louisville's Institutional Repository

Electronic Theses and Dissertations

1936

\title{
The Know-Nothing party in Louisville.
}

Carl R. Fields 1910-2000

University of Louisville

Follow this and additional works at: https://ir.library.louisville.edu/etd

Part of the Public History Commons, and the United States History Commons

\section{Recommended Citation}

Fields, Carl R. 1910-2000, "The Know-Nothing party in Louisville." (1936). Electronic Theses and Dissertations. Paper 1786.

https://doi.org/10.18297/etd/1786

This Master's Thesis is brought to you for free and open access by ThinkIR: The University of Louisville's Institutional Repository. It has been accepted for inclusion in Electronic Theses and Dissertations by an authorized administrator of ThinkIR: The University of Louisville's Institutional Repository. This title appears here courtesy of the author, who has retained all other copyrights. For more information, please contact thinkir@louisville.edu. 
University of Louisville

\author{
The Know-hothing Party in Louisville $r$ \\ A Dissertation \\ Submitted to the Faculty \\ of the Graduate School of the University of Louisville \\ In Partial Fulfillment of the \\ Requirements for the Degree of Naster of Arts
}

\author{
Department of History \\ by \\ Carl R. Fields \\ Yegr
}

I) 96 


\section{CONTEISS}

CHAPTER

PAGE

Introduction

I) The know-Nothing Party in the State and the Nation ........... 3

II. The Beginning of the Know-Nothing Party in Louisville.......... 11

III. The spring Election of $1855 \ldots \ldots \ldots \ldots \ldots \ldots \ldots \ldots \ldots \ldots \ldots \ldots \ldots$

IV. The Election of August 6, 1855 - "Bloody Monday"............. 38

V. The Know-Nothings and the Election of $1856 \ldots \ldots \ldots \ldots \ldots \ldots \ldots \ldots$

VI. The Persistence of Know-Nothingism in Louisville ........... 81

VII. The Know-Nothing Party Eecomes the Opposition ...............94

VIII. Conclusion $\ldots \ldots \ldots \ldots \ldots \ldots \ldots \ldots \ldots \ldots \ldots \ldots \ldots \ldots \ldots \ldots \ldots \ldots$

Bibliography i i 
Introduction

During the course of American history there have appeared at frequent intervals movements of opposition to Catholics and foreigners. Sometimes these movements have emanated from urban centers, sometimes from rural communities; sometimes the movement has been merely of local interest and at other times the opposition to Catholics and foreigners has reached such proportions as to be of major importance to the entire nation. One can understand that in the days of our infancy as a nation we were jealous of our nowly won freedom which meant freedom from European religious intolerance and political oppression; one cannot as easily understand why the nativist movement and the anti-Catholic movement have so persistently maintained their importance throughout our history.

The various organizations against foreigners and Catholics are not separate movements. If one were to trace the history of such organizations one would find that the position the foreigner and the Catholic were to occupy in the United States has been an ever-present problem. This is one fact to be carefully noted because it lends significance to the study of the nativist movement in any particular period. For a study of the causal factors in the rise of a nativist movement one mast take into account the entire history of the United States.

The fire of nativist sentiment, ever-present, is sometimes in a smouldering state and is frequently rekindled by the events of a relatively brief period of time, say a decade. These immediate causes are more apparent than the more fundamental ones and, therefore, their importance is sometimes exagerated. Such a period was the decade 1850-1860, when perhaps the strongest anti-foreign, anti- 
Catholic movement played such a powerful role in American politics.

The nativist morement in the 1850 "s helped to delay the conflict over slavery and served also to emphasize the importance of the Union. Most of the men in the United States with nativist sympathies sincerely believed that the great issues of slavery and states rights could be avoided by turning the attention of the people of the United States to a greater menace, forelgn and catholic influence. Whether or not some men were emphasizing the anti-foreign problem for personal gain, I am not prepared to say; yet it is doubtloss true that the nativist movement of fered more opportunity to 80 mo individuals than either the issue of states rights, or slavery. While the nativist movement helped to postpone the slavery issue, its eventual failure showed the irrepressible nature of the slavery controversy. Every weapon atailable to political machines as woll as sincere, honest men, secrecy, incendiarism, intimidation, murder, and many others were used in a vain effort to turn peoples' minds from the burning issue of the hour, slavery; but inevitably the specter of the "African" problem loomed up to inflame anew the passions of a William Lloyd Garrison or a Robert Toombs and take the place of tho "American" problem.

A brief background of nativist development in the 1850"s will set the stage for a discussion of the nativist growth and activities in Louisville, Kentucky, which was one of several southern cities where nativist feeling was very strong. 
CHAFTHR I

THE KNOW-NOT-INC PARTY IN TEE STATE AID THE MAT ION 


\section{CHAPTER I}

The Know-Nothing Party in the State and the Nation

In 1850 there was organized in Now York City the "Order of the Star-Spangled Banner", a nativist group, which under its founder and leader, Charles B. Allon, was destined to grow into a national nativist political partty. (1) For approximately fortythree years the nativist movement had attracted the attention of a few people, but for the most part the success of these earlier societies had been temporary. At the time of the organization of the "Order of the Star-spangled Banner" the most powerful nativist order in the East was the Order of the United American Mechanios. By 1852, however, many members of this order had joined the "Order of the Star-Spangled Banner", which had a much better organization, and was beginning to make an impression in local Now York politics.

"In default of a better name it (Order of Star-Spangled Banner) was duhbed the "know-Nothing" order by an interested public, and under that name the order of the Star-Spangled Bannar thenceforth pursued its career. The proper name of . the society was tinat of the supreme order of the starSpangled Banner." (2)

The name "Know-Nothing" was given to the order because when the members of the order were questioned about their party, they invariably replied, "I know nothing". A previous nativist party had called itself the "American Party", and after the secret machinery of the Know-Nothing party had been discarded in 1856, the namo "American party" was adopted. That was always the offictal name, and not the "Supreme Order of the Star-spangled Banner". (3)

(1) Scisco, L. 0., Political Nativism in New York State, New York;

(2) Thid., pp. 67, 80. Columbia University Press, 1901, p. 66.

(3) "After the secret machinery was discarded, the party called itself the "American" party. However, it was always popularly 
The American Party was a vast secret organization with ramifications in many states. Those desiring to be members of the party must be twenty-one years of age, belleve in God, be born in the United States, have no Catholic relations, and be reared under Frotestant influence. For a long time the American Party, as it was officially known was very successful in its efforts to maintain secrecy as to its activities. Secet knocks, secret conversations, secret passwords, secret meetings and announcements of meetings veiled the politics of the party and attracted many members. Many amusing observations were made about the party, one writer pleturing the party meoting in ghostly, unholy places, members carrying dark lanterns, and all pledging terrible oaths. The seorecy of this party gave them an influence in politics because of the inability of the other parties to cope with them. The American party until 1855 had no political platform and openly nominated no candidates. Aftor much discussion, they agreed on the candidates of one of the other parties and cast the entire party vote for him. (4) It is not surprising that most amaing results on election day occured.

The party was organized much as our political organizations known as the "Know-Nothing'party . The official name of the order and of the party was alwavs the American party and not the "Supreme Order of the Star-Spangled Banner" as stated by James Ford Rhodes in his history . . I have been assured by the recording secretary of the National Council and several of the surviving members of the party that it never had any other name officially than the American party." --Schmeckebier, L. F., History of the Know-Nothing Party in Maryland, John Hopkins Press, 1899. $\mathrm{pp} \cdot \overline{9}-\overline{10 .}$

The two authorities quoted above differ on the official name of the know-Nothing Party. It is probable that after the party obtained national importanco, the name American Party was aocepted as the official name.

(4) Perrin, History of Kentuoky, p. 328, says, ". . at first their nominations were made from the other political parties, and by their secret and united weight they would generally turn the scale as to them meet." 
are today. There was the ward or district council, the city or superior council, the grand council or state council, and the national council.

A series of degrees bound the members in oath to abide by party decisions. Two degrees were established early in the party"s existence, and in 1854 at the National Convention in Cincinnati, Kenneth Raynor of North Carolina proposed a third degree, or Union degreo "having as its specific purpose the preservation of the Union." (5) Members of the party taking this oath were bound to "spend themselves" in order that the Union might be saved.

A quotation from the Lonisville Weekly Journal rather adequately explains the general feeling about the Know-Nothings. "These fellows have no conventions, say nothing, do nothing. Silent, secret, self-possessed, veiled in impenetrable mystery, they contemplate from their hiding places the progress of the strife and will prohably pitch in and terminate the battle in their own way." (6) Growth of American Party

By May 1, 1854, there were fifty-four (54) local know-Nothing organizations in the United States. In 1854 the Know-Nothing party swept Massachusetts and New York, electing a Governor and practically the entire legislature. Gardner, Massachusetts" candidate for governor, was elected by a majority of 50,000. Henry Wils on was sent by the Republican Party to the Senate, and all the Representatives elected were Know-Nothings.

(5) Wilson, $\mathrm{H} .$, Rise and Fall of Slave Power in America, Boston: Orgood, $1872 . \overline{\text { P. }} \overline{421}$.

(6) Louisville Weekly Journal, August 21, 1854. (At the time this comment was written, the power of know-Nothings had been felt in 2 Louisville election, August 7, 1854.) 
In the New York election, 1854, the Know-Nothings elected

a know-Nothing governor and forty members of the state legislature.

In Fennsylvania, the Know-Nothings helped elect a governor and some members of the legis lative body.

In 1855, the Know-Nothing party elected governors in Massachusetts, Connecticut, Rhode Island, New Hampshire, Colorado Kentucky, and the party controlled the legislatures of all these states except Now Hampshire. In New Hampshire, Maryland, and Tennessee, the legislatures were controlled by a fusion of Whigg and Know-Nothings; and the legislatures of New York, Georgia, and Louisiana had strong Know-Nothing minorities.

The know-Nothing party spread rapidly westward. By July, 1854, there were $1,000,000$ adherents to the party; there were 80,000 in Ohio alone, and the party estimated that the membership was increasing in Ohio at the rate of 2,000 per day. Cincinnati, in the latter part of 1854 , boasted 7,000 to 8,000 Know-Nothing members. (7)

Kentucky was regarded as a stronghold of the know-Nothing party. For the state as a whole this was probably due to the fact that Kentucky had been very strong for the preservation of the Union. In the know-Nothing party it seemed, for at time at least, that the Union would be preserved by concentrating public attention on national rather than on sectional issues. For some time Kentucky newspapers had been calling attention to the importance of insuring national unity. In 1850 the Louisville Daily Journal had said "The Union, it must be preserved". (8) As the leader of the Whig party, Henry Clay had advooated the formation of the National Union Party.. This,

(7) Louisville Daily Journal, October 10, 1854

(8) Louisville Daily JournaI, January 3, 1850. 
of course, did not mean that Henry Clay would have favored the KnovNothing party although many of his friends later joined that party. Mr. James Speed, in a letter to Mr. William. Rhompson of Shepherdsville, dated March 26, 1855, said, "No one can pretend that Mr. Clay ever was or ever could be a Know-Nothing .....yet, strange to say, that party which he led so long, composed mainly of personal admirers, it is said have formed a secret junto, or clique, to accomplish their wishes. Much as I dislike slavery...... would not aid in organizing a secret party to effect that object".... Further, Mr. Speed characterized the Know-Nothing party as a party made up largely of Thigs, a party that was non-committal concerning the question of slavery, a party that was also evasive to all questions concerning its platform or its purposes, a party that was a secret, oathbound organization.

There are some who regard the success of the know-Nothing movement in the South and in Kentucky as somewhat of a mystery. (9) It is, however, not surprisine that Kentucky and other southern states should have been drawn to the know-Nothing party. "rith the breakup of the Thig party to which we shall refer later, the Sough had two main objects in mind; maintenance of Sourthern position in national politios, and the evasion of the slavery issue. The rapid influx of foreigners had greatly increased the power of the North, and the South took to the know-Nothing in self-defense. In addition, Kentucky being a border state, the foreign-born element and consequently the Catholic were quite numberous as we shall see later on. (10)

(9) James Robertson, in the ivississippi Valley Historical Review, Vol. IV, p. 52, says that the "stronghold the Know-Nothing party had taken on the population of Kentucky is one of the peculiar facts of its political history." He further asserts that this power was also peculiar because of the small foreign element in the state and the comparative harmony of the Catholic and Protestant churches. 
Kentucky had never been a very strong Democratic state; the last Democratic governor to hold of ice in Kentucky being John Breathitt, who had been elected in 1832. Not until 1851 did the Dewocrats succeed in electing a Democratic governor, and not until 1856 was the electoral vote of Kentucky cast for the Democratic party. The appearance of a new Democratic party strength in Kentucky In 1851 was caused by the gradual weakening of the old Whig party. The Thig party had been the party of power in Kentucky, but they had opposed the adoption of a new constitution in opite of the popular demand for it, and were thus put in a rather unpopular position. Consequently when the constitution wes finally accepted, the Democrats claimed credit for having "ushered in a new ere of real democracy". The people were reminded time and time again that the Dewocrats had made this possible. One notable change that worked for the advantage of the Democrats was the provision that the time for voting in state elections should be reduced from three days to one. Heretofore. Whig wealth had taken full advantage of the long time allowed to vote. (11)

A democratic governor, Lazarus W. Powell, was elected in 1850, and the Whig cause had begun its decline. As early as 1848 Henry Clay had said "I fear the Whig party is dissolved". The most telling Dewocratic triumph in the early 1850's was the

(11) Conneliy and Coulter, History of Zentucky, American Historical Society, Chicago and New York: Vol. 2, p. 842.

(12) Colton, Private Correspondence of Henry Clay, p. 567. 
election of John $C$. Breckenridoe to the fouse of penresentutives from a hide-hound hig stronohold, sshlind.

"The final downfall of the hirs in Kentucky and in the nation was broupht about by the so-called Zansas-Nebraska Bill, introduced in the United Stutes senate by Sentor Dodre of Iowa, in December, 1853." (1.3) The Kansas-ivebrask Eill would have heen ineffective as far as slavery migration was concerned if the rissouri Compomise was still operative and "so at the instigation and insistence of Archibald Dixon, the new Whig Senator from Kentucky, the issouri Compromise was specifically repealed in a separate clause of the bill." (14) Thus was the work of the Compromise of 1850 forever undone; the country was throm into "extreme excitement and turmoil, and the whig party was doomed." In the Northest, a party with the single ob iect of combating the spread of s]avery made possible by the Kansas-Nebraska Rill was demanted. This the uhif varty could not be." (15) Southern thigs thoucht very differently on the ruestion of slavery from Northern Whigs; ant so party chaos reigned for a time, until the elements could be grouped into a new party. Wany of the orstwhile. whigs, having no other place to go, ioinet a secret organization mach live the nativeAmericans and popularly known as the Know-Nothine party. "It gave them the ioy of a fool's daratise for a time, where they could forget the gaping sectiond wounds and contemplate things with wich they were only remotely connected and which constituted not the slightest problem for them. The ignored slavery and the menacing ouestions it produced to run into rented discussions on the dangers of foreigners and Catholics." (16)

(13) Connely \& Coulter, History of Kentucky, American Fistorical Society, Chicago, Vol. ?., n. 844.

(14) Rhodes, History of the United States, 1850-1909, New York; Mackillan, 1928, Vol. I, D. 175. Dixon was filling unexpired term of Clay.

(15) Nillis, p. 175

(16) nillis, p. 175,176 
It is undoubtedly true that many politicians from the ranks of the dying Wig party took a new lease on life by allying with the know-ilothing party. Ihis fact partly accounts for the rapid increase in the strength of the know-Nothing party during its inception. The Louisville Teekly Courier, for example, criticised two "old party" men, W. D. Pilcher and Humphrey Marshall for "seeking to advance themselves b' ricing into power on the popularity of a new organization." (17) Both of these men had been Thigs, Humphrey Marshal a fairly prominent leader. He was born in Frankfort, Kentucky, in 1812, and spent most of his life in the state of Kentucky. In 1832, he graduated from Test Point, and the following year year he began the practice of law in Frankfort. In 1849 he elected to Congress on the Thig ticket. In 1852 he was appointed minister to China. He joined the know-Nothing perty in 1854 and served in Congress from 1855-1859. Then the Civil war came, he sided with the Confederacy. He left Kentucky, and after the end of the war he was permitted to roturn to the state where he practiced law until his death. (18)

A feeling was expressed in several quarters that either the Know-N things would attract "old broken-down politicians," (19) or they would elect men "unhackneyed in political ways." (20)

So, in Kentucky where the main tenets of Know-Nothingism were not very popular, the remains of that party which Henry Clay had led for so long, joined the ranks of the Know-Nathings. (21)

(17) Louisville Neekly Courier, February 17, 1855

(18) Dictionary of Amer ican Biography, Vol. XII, pp. 310-311.

(19) Louisville Weekl\# Courier, February 19, 1855.

(20) Louisville Daily Journal, December 19, 1854.

(21) See footnote (14), page 9. 
CHAPTER II

BEGINNINGS OF THE KNOW-NOMHING PARTY IN LOUISVIILE 


\section{Beginning of the Know-Nothing Rarty in Louisville}

The exact date of the beginning of the know-Nothing party in Louisville cannot be easily determined because of the secret nature of the party. Actually the party had been formed and had taken an active part in a city election before much interest in the movement had been aroused. Frior to the August election, 1854, about all that was known in Louisville about the Know-Nothing party was rumor. The Louisville Teekly Couriertold about this order with its "flash title" in February 1854 stating that the "only uniform or insignia to be worn is a white eagle of silver or plated metal on the left breast".

As the time for the election in August, 1854, drew near some indication of the presence of a know-Nothing organization was felt; indeed one newspaper carried the following reference to know-Nothirg activity: "It is rumored that the know-Nothing will wield the balance of power in the coming contest for city and county offices". (2) Three or four men who were elected to a city or county office in this election of Friday, August 11, 1854, were thought by many Louisvillians to be know-Nothings. Without any apparent concerted effort the native Americans and the German element came to blows on this election day, foretelling in a rather unpleasant manner, the grief that was to come to Louisville when the issues between the Know-Nothing organization and the Democrats were clearly drawn. Several fights occurred throughout the city, "the most serious fight .....off somewhere on Fifteenth Street, between a party of Germans and Americans". In this particular skirmish the Americans came out

(1) Louisville Weekly Courier, Saturday, February 11, 1854. (No other reference to an insignia of this kind has been found by the author.

(2) Louisville Daily Courier, July 19, 1854. 
second best. (3)

Some indication of the working methods of the Know-Nothinge was given in this election for, contrary to the usual political methods, "those who had the least to say and were almost unknown on the stump were triumphantly elected". (4) This method of secretly endorsing a candidate was one of the most powerful weapons of the know-Nothing party. This secret endorsement of candidates really was a nomination and this fact gave the know-Nothing organization quite an advantage for "the tendency ws general to ignore for the most part party lines and designation. Men were voted for on their merits. But in Louisville and a few other efties the Know-Nothing organization came out and succeeded in carrying its candidates into office".

The power of the know-Nothing party had not only been demonstrated in the Louisville election of August, 1854, but in various other parts of the West the Know-Nothings had made themselves felt. Far from being a Northern or Eastern party, the Know-Nothings had gone as far West as St. Louis and had taken an active role in the Missouri state elections. (6)

After the election of August, 1854, the presence of the Know-Nothings in Louibville became more than a rumor. (7) The knowledge of the Know-Nothinge presence increased the respect of the local politicians for that organization (8), and also led to many efforts to expose Know-Nothingism. On September 2, 1854, "a rally of true blues was called for the purpose of staying that hydra-headed monster ealled "Know-Nothingism..... we shal shake no sable plumes

(3) Louisville Daily Courier, August 3, 1854.

(4) Louisville Daily Courier, August 9,1854

(5) Connelly and Coulter, History of Kentucky, p. 845.

(6) Louisville Weekly Cour ier, August $26,1854$.

(7) Benjamin J. Webb, A Centenary of Catholicity in Kentucky, Loutisville: Rogers, 1884 . p. 483 .

(8) Loufisville $D_{2}$ ily Courfer, August 12, 1854. 
over Know-Nothingism until it fails to meet us at the ballot box." (9)

Wile the presence of the nativist party in Louisville had been known

for some time the press did not attach any particular significance to the movement until the closing days of 1854./ In November the Louistille Weekly Courier carried the following significant editorial:

"The body of Know-Nothings has become so strong in this eity, that as soon 28 political aspirations spring up their owners turn inquiring oyes toward the know-Nothing lodges and seem to inquire plaintively and meekly, is it by your leave? It was formerly the case that men were begged to run for office, now they have to beg the know-Nothings to let them run." (11)

The Lousiv1110 Demoorat had called the attention of the people to the presence of a Know-Nothing organization in the city and had expressed some little apprehension over the secret nature of the party. The Louisville Daily Journal had said, "wo outslders, who know nothing about the know-Nothings and their purposes are sometimes amused at the fierceness with which some of the Now York papers quarrel about this new element in politics". (13) Ironically enough, a few months after this statement was written, the editor of the Daily Journal, George D. Prentice, was villified by the press of the nation as the instigator of a bloody riot in Louisvillo because of his vitriolic utterances against the anti-Know-Nothings.

In 1854 the Louisville Daily Journal, edited by Prentice, "the most influential editor in the South" and a "staunch Union man" (14), had not openly sided with the know-Nothing movement. Those who saw the Whig party gradually losing its hold in the South criticized Prentice for not making an immediate stand against the new party but Prentice, saving ".. I do not know

(9) Louisville Neokly Courier, Sept. 2, 1854. (10) Louisville Daily Journal, Sept. 19, 1854. (11) Louisville Teekly Courier, November 25, 1854.

(12) Louisville Daily Journal, December $19,1854$.

(13) Louisville Daily Journal, December 14, 1854.

(14) Cotterill, R. S., The Old South, Arthur H. Clark Company, Glendale, California, 1936 . 
what their principles are", did not openly condemn the party. This much he could and did do: he elearly stated that he was against any secret organization, especially of a political nature. (15) Further, Prentice at this time protested against the Know-Nothing practice of discrimination against foroigners and Catholics which he regarded as a violation of rights. By discrimination Prentice meant restriction of roting and exclusion from office:

As the controversy over Know-Nothingism increased the Louisville Daily Journal soon found itself folldwing the example of many Whig newspaptrs in defending the Know-Nothing cause. (16) The following quotations show the attitude of the Louisville Daily Journal in its first efforts for the knowNothing party;

1. Nith regard to the Know-Nothing opposition to slavery the Louisville Daily Journal said, "Wo know of no other purpose that can occupy the attention of any man or set of men than the effort to terminate the agitation of this irritating subject of slavery and if the know-Nothings propose to take up this subject and settle it permanently we say God speod them in this, their patriotic labor." (17)

2. A New York paper said the Know-Nothings were in the hands of the "Union Savers" and the Louisville Daily Journal wrote that if the Know-Nothing cause was in the hands of the Union savers they were "pretty good hands for any national subject to be placed. If there, is...a determined purpose in this new organization, to quiet and adjust this slavery agitation, we trust that it will be done, and that in so doing they will place it within the pole and

(15) Louisville Daily Journal, August 23, 1854.

(16) Three strong Thig Journals changed their names: the Jackson Southern became the Flag of the Union; the Oxford Whig became the Star of the Union; and the Carrollton Whig became the Union Flag.

(17) Louisville Daily Journal, $\mathrm{N}_{n}$ vember $23,1854$. 
protection of the Constitution--it will never be beyond the reach of agitation until it is there." (18)

3. "No are, as our readers are well aware, no advocates of the KnowNothings, but we feel it our duty to vindicate every party against palpably unjust imputations..... We cannot but entertain a hope, that, in some things it (the know-Nothing party) will exeroise beneficient influences.....The Foreign influence is too much wooed." (19).

4. "There may be errors and important ones, in the creed of the know-Nothing or American party, but we again say that a party of sounder nationality does not exist." (20)

Some explanation of the causes for the spread of the Know-Nothing party in Kentucky and Louisville have been given but the importance of the major principles of Know-Nothingism, anti-Catholicism and opposition to the forelgners wot now be shown. Was the foreign element in Louisville very strong and were their many Catholics in Louisville? This question requires rather careful analys is.

It should be pointed out that the tide of foreign immigration had increased very much and that one cause for the tension between the North and the South was the decline in the political importance of the South due to the rapid influx of foreigners into the North. Foreigners were attracted to the anti-slavery party because of their lack of experience with slavery in European countries and because they were strong nationalists.

(18) Louisville DaiTy Journal, Novemrer 24, 1854.

(19) Ibid., February 1, 1855.

(20) Ibid., April 6, 1855, ( Other views on the Louisville Daily Journals" espousal of Know-Nothingism will be shown. 
The following chart shows the trend of immigration from 1790 to $1855:(21)$

\section{Arrival of Forefigners}

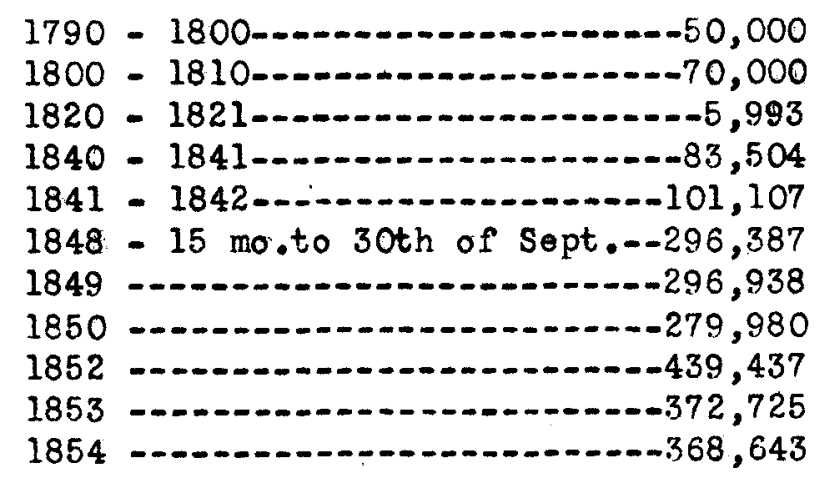

$1,866,397$ persons of foreign birth in non-slave-holding states and 378,205 in the slave-holding states.

$$
\begin{aligned}
& 19,948,417 \text { - total native and forelgn population } \\
& \frac{17,737,578}{2,210,839} \text { - born and residents in United States }
\end{aligned}
$$

(21) United States Census of 1850, Statistical View of the United States by J. D. B. DeBow

Washington: A. O. P. Nicholson, Publio Printer, 1854. 
A little clearer idea of the immigration problem may be formed from the following chart which shows the distribution of foreigners in several of the etates. (22)

\begin{tabular}{|c|c|c|c|c|c|c|c|}
\hline & & $\begin{array}{l}\text { No. born } \\
\text { in state }\end{array}$ & $\begin{array}{l}\text { No. born outside } \\
\text { state in U. S. }\end{array}$ & $\begin{array}{l}\text { No. born in for } \\
\text { oign countries }\end{array}$ & & Unknown & Total \\
\hline & ' & & 1 & 1 & ' & & , \\
\hline Alabama & 1 & 234,691 & 183,324 & : 7,498 & ! & 1,001 & 426,514 \\
\hline Arkansas & : & 60,996 & 98,950 & 1,468 & ; & 775 & 162,189 \\
\hline De laware & : & 55,591 & " 10,326 & : 5,243 & : & 9 & : 71,169 \\
\hline Georgie & ; & 396,298 & 118,268 & : 6,452 & : & 554 & 521,572 \\
\hline Illinois & : & 331,089 & "399:,733 & 111,860 & " & 3,352 & 846,034 \\
\hline Indiana & ! & 520,583 & '398,695 & i 55,537 & ! & 2,339 & 977,154 \\
\hline Kentwaky & ! & 580,129 & $" 148,582$ & 31,401 & ; & 1,301 & 761,413 \\
\hline Louistana & ' & 126,917 & " 60,641 & : 67,308 & : & 625 & 255,491 \\
\hline Maryland & & 326,040 & " 40,610 & : 41,011 & ! & 282 & 417,943 \\
\hline Missouri & : & 265,304 & $: 249,223$ & $: 76,570$ & ! & 907 & 592,004 \\
\hline Now Jersey & : & 361,691 & 43,711 & 59,804 & 1 & 303 & 465,509 \\
\hline New York & & $, 092,076$ & 296,754 & ! 655,224 & ' & 4,271 & $3,048,325$ \\
\hline North Carolin & & 529,483 & : 20,784 & : 2,565 & ! & 196 & : 553,028 \\
\hline Ohio & 1 & $, 203,490$ & 1329,208 & ' 218.099 & ' & 4,253 & $1,1,955,050$ \\
\hline Pennsylvania & 1 & $, 787,310$ & "165,966 & 303,105 & ; & 1,770 & . $2,258,160$ \\
\hline South Carolin & & 253,399 & 12,601 & i 8,508 & ' & 55 & 274,563 \\
\hline Tennessee & ' & 580,695 & 168,966 & : $\quad 5,639$ & i & 1,537 & 756,836 \\
\hline Texas & ' & 43,281 & : 92,657 & : 17,620 & : & 476 & 154,934 \\
\hline Virginia & ! & 813,311 & ' 57,582 & ' 22,953 & ' & 454 & 894,800 \\
\hline
\end{tabular}

We can see from this chart that the preponderance of immigration from foreign countries was in the North and for that reason the South feared (22) United States Census of 1850 
the political influence of the foreigners. -Note that the border states of the South had numbers of foreigners much larger than the other southern states. By 1860 the foreign-born population in the United States had increased to $4,136,175$ persons. The increase since 1850 in some of the southērn states was as follows:

Foreigners - Increase from 1850 to 1860

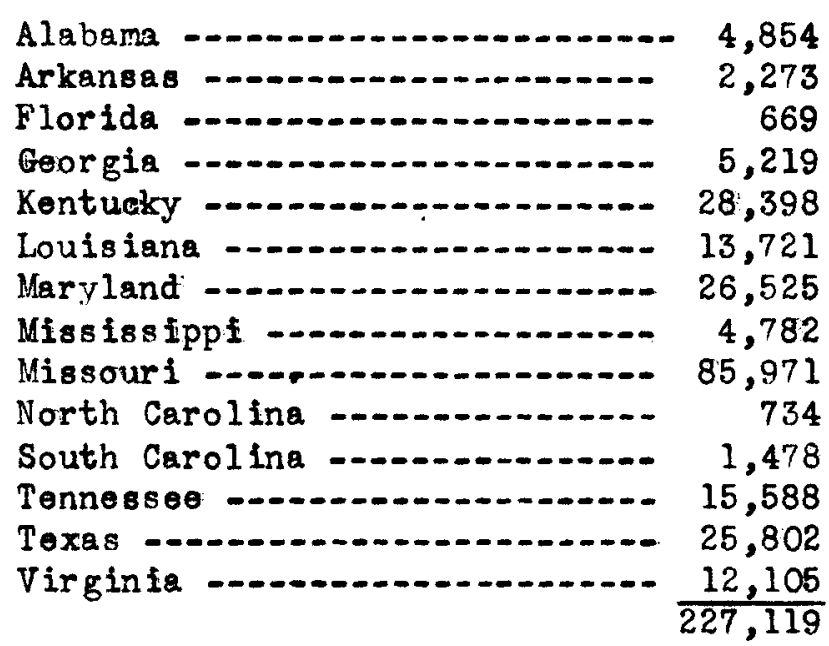

Juding by the proportion of foreign-born in the various states in 1850 and the slight increase in the Southern states we see that most of the Immigration into the United States was into the Northern states. While the foreign-born population had about doubled in the period 1850-1860 less than 230,000 had entered the so uthern states - "The states of the Lower Mississippi Valley, and the southern border states in the Valley of the Potomac and Ohio, Rivers contained nearly ninety percent of the foreign-born population of the South and a large portion of the foreign immigrants were massed in the large cities, where they nearly equalled in numbers the native-born population. (23) Only in Louisville, New Orleans, Baltimore, and Savannah did the foreign-born

(23) Cole, A. C., The Whig Party in the South, American Historical Association, $\overline{1913}, \overline{\mathrm{p}} \cdot \overline{309}$ Debow, Census 1850 
element constitute more than one-third of the population.

In the early days of the appearance of the American party in Louisville the foreign question loomed large in the editorials of the Louisville newspapers: The Loulsville Daily Journal, the organ of the know-Nothing party said, "From all I hear and see around me it is evident that this foreign question is to override all others, even the slavery question, as we see men of the most opposite views on slavery, forgetting their differences and acting together." (25) In this same issue this further statement was made, "What the American party fears is the growth of the political influence of the foreigners.not physical violence, but political force is not feared by the American party. The balance of power is with the foreign votes. They are united and are usually arrayed on one side". (26)

The Louisville Weekly Couriertook a slightly different position in opposing the foreign influence. That paper saw in the vast imports from other counties still another effort on the part of foreigners to undermine American institutions. "In 1853 imports from foreign countries totalled $\$ 268,000,000$. Of that amount only $\$ 31,000,000$ worth of goods could not have been produced in the United States. The remainder should have been produced in America by American workmen. Oh: Sam, isn't Amerlcan cloth fit to make a coat of." (27) In a tone similar to that taken by the Louisville Daily Journal the Courier regarded "foreign influence as a dangerous thing in a country like ours. European countries would be glad to see our institutions abolished. The only way to guard our institutions is to exclude foreigners from office, and lengthen the time they must stay in America before becoming citizens." (28)

(24) DeBow, Census 1850

(25) Louistille Daily Journal, January 15, 1855. (26) Ibid.

(27) Louisville Weekly Courier, December 2, 1854.

(88) Louisville Weekly Courier, May 10, 1855 
In Louisville we find that there were many Catholics and foreig-

ners. The proportion of Catholics and foreigners living in Jefferson county had a total population of 59,831, an increase of 19,485 over 1840. Of the total population, 15,782 , or one-fifth were foreign-born--five times as many as in any other county in the state. Kenton county was next to Louisvillo in the number of forelgn-born population, having 3,364. (28) Probably in Louisville, where there were many Germans and many Irish of the servant class, the foreign-born element constituted well over one-fourth of the population. (30) The largest body of foreigners in the Ohio Valley was German. Cities like Cincinnati and Cleveland had a German element that was about equal to the native-born political strength. "Wany of the new arrivals were political exiles from their native lands. They began at once to organize by establishing political clubs in the large cities. In January, 1852, a German Revolutionary Congress met at Philadelphia attended by delegates from several Revolutionary Unions. In 1854 an association of "Free Germans" was formed 'for the purpose of being able to exercise a power proportionate to their numbers and adopted to their principles", with headquarters at Louisville and branches in all the principle cities of the Union." (31) The Irish Emigrant Society was also established in Louisville. A platform of principles was published and a program of measures for the reform of our government adopted to the enlightened rule of foreign revolutionists. Included in these liberal principles were statements that "religion is a private matter". (32)

(29) In November, 1854, the school trustees of Louisville introduced the teaching of corman into the First Ward schools. A majority of the

people in that Tard were German "One member of the voard thought that all the education imparted should be strictly native American". See: Louisville Daily Courier, November 15, 1854.

(30) Mr. Templo Eodley, a reliable historian, was living in Louisville furing the period of Know-Nothing supremacy. He told the author that the foreigners were very powerful in Louisville. He also attributed the large foreign element in Louisville to the fact that so many servants were Irish.

(31)Cole, mig Party in South, p. 314.

(32) Abbott, Edith, Historical Aspects of Immigration, Select Documents, University of Chieago, IIl inois, p. 504 . 
The Free Germans were opposed to "Sabbath laws, Thanksgiving days, prayer in the Congress and the legislature, oath upon the Bible, introduction of the Bible in free schools, exclusion of atheists from legal acts" . (3) Further, according to the Free Germans "admission to citizenship should be rendered as easy as possible to immigrants". (34) The fear of radicalism was one thing that caused a violent reaction against the foreign element. The Union of Free Germans in Louisville at one time advocated the abolition of the Presidency and the Senate, the abrogation of Sunday laws and oaths taken on the Eible, and other reforms that greatly aroused the members of the know-Nothing party. On the question of slavery a leading German paper had said, "Since the maxim of slavery is established 'No union without slavery" the friends of humanity are obliged to lament the passing of the Union". (35) The Louisville Daily Journal said, "All we desire is to show our people that the foreign populaticn have banded together by secret associations to tinker at the (Know-Nothing Party) and pervert its purposes and designs". (36) The Daily Journal was suspicious also of the "screen of a foreign language".

In Louisville and many other cities, particularly southern cities, the presence of German communties had caused considerable trouble. The customary Sunday religious observances were many times distegarded by the liberal thinking Germans. Many opponents of the American party scoffed at the idea of including in the American platform of 1855 the acknowledgment of the existence of God. "It was asserted that a very large proportion o f the Germans, who compose a very large proportion of the anti-American party, are infidels, who: scoff at the idea of God as the mere figment of an addled brain." (37)

(33) Abrott, Edith, Historical Aspects of Immigration, Select Documents, (34) Ibid., p. 505 . University of Chicago Press, Chicago, Illinois, p. 504.

(35) Louisville Daily Journal, July, 1856

(36) Ibid., July $21,1855$.

(37) Ibid., July 18, 1855. 
Frequently Sunday liquor gatherings, sonetimes numbering in 12,000, aroused the prose of Louisville against the inconoclastic Germans. Because of the strength of the foreigners and their apparent disregard for American standards many poople heralded the arrival of the American party. The Daily Democrat was pleased at the organization of the "American Party, or Association.....they are gathering around the standard of morality and republicanism:" (38)

The German reaction was rather pronounced, many of them threatening to discontinue the Democrat unless the series criticising German liberality were banned. Wany German elements, protesting against the "sham of liberty" contemplated the organization of a new political party. (30)

In 1855 aforeign secret society, according to the Louisville Weekly Courier, was organized in Louisville for the express purpose of opposing the American party. Three clubs were organized in every ward and were composed of Democrats and foreigners although the Democrats disclaimed membership in the "Sag-Nicht Farty", as the new group was called. The real nature of the Sag-Nichts' purpose is shown in the platform of principles laid down in a convention in Columbus. First, the organization pledged itself in hostility to nativism in every shape and especially to the extension of slavery. Second, the Sag-Nichts pledged themselves to receive and welcome all foreigners. The Louisville Daily Journal had considerable respect for the Democratic political machine composed of Democrats, foreigners, Catholics, and a few "old line" Whigs. According to the Louisville Daily journal " the majority of the political opponents are Germans, Irishmen, and other foreign-born citizens. The general issue is between foreignism and Americanism". (40)

In 1841 Louisville had a population of 47,460 . The chart on the next page gives the approximate strength of in the various denominations

(30) Daily Democrat, May 16, 1854.

(39) A. C. Cole, The Irrepressible Conflict, 1850-1870, Mackillan \& Company, $1934, N, Y, \overline{p p} * 141,142$.

(40) Louisville Daily Journal, July 9, 1855. 
in Louisville in 1850. (41)

\begin{tabular}{lccr}
\hline Denomination & $\begin{array}{c}\text { Number of } \\
\text { churches }\end{array}$ & $\begin{array}{c}\text { Number people } \\
\text { accomodated }\end{array}$ & $\begin{array}{r}\text { Value of } \\
\text { property }\end{array}$ \\
\hline Baptist & 12 & 4,920 & 1,240 \\
Christian & 3 & 1,350 & 19,300 \\
Episcopal & 4 & 1,650 & 52,350 \\
Jewish & 1 & 600 & 13,000 \\
Lutheran & 3 & 1,750 & 18,500 \\
Methodist & 20 & 10,380 & 111,300 \\
Presbyterian & 10 & 5,450 & 136,100 \\
Roman Catholic & 4 & 7,140 & 120,000 \\
Unitarian & 1 & 700 & 15,000 \\
\hline
\end{tabular}

In 1853 the Catholic Diocese of Louisville, which had been created

in 1808 , embraced the entire stae of Kentucky and was presided over by Bishop. Martin L. Spaulding, who had succeeded Bishop Kerrick on June 11, 1854. In his diocese there were fifty-six churches, eighty-eix chapels and other stations, forty clergymen, one ecclesiastical seminary, thirteen literary instituions, and a Catholics population of 45,000 . This would mean, on the bas is of the population of Louisville and the rest of the state, that Louisville had approximately twice as many Catholics in proportion as there were in the rest of of the state.

Throughout the whole story of the know-Nothing party there were many controversies with the Catholics. It is desirable to: point out one or two major points of difference between the know-Nothings and the Catholics. In the first place the Know-Nothing adherents denied that Catholics could be one hundred percent loyal Americans. The Louisville Daily Journal and other Know-Nothing newspapters endeavored to prove that the Catholics were bound to consider their allegiance to the church as paramount to the state and to consider the power of the Pope as the supreme authority. The Louisville Daily Journal quotes a statement of Innocent III to the offect that "it is necessary for salvation for everyone to be subject to the Roman pontiff". (42) Regarding one"s relationship to his country the above statement fairly representative

(41) DeBow, J. D. B., Seventh Census of the U. S., 1850, Superintendent United States Census: Washington, 1853. pp. 643, 635, 637-639.

(42) Louisville Daily Journal, July 3, 1855 
of the general idea held by Know-Nothings regarding Catholics. Not only that, but also the know-Nothings condemed the Catholics as foes of religious liberties. "No fect can be established by plainer and more incontrovertible evidence than the fact that genuine, Orthodox Roman Catholics, believing in the doctrine of the Popes and the Roman Catholic church in all the ages of its existence, are the inexorable foes of religious liberty.....the allegiance of Americans to a Roman potentate is not the allegiance of American citizens." (43)

In the opinion of the Know-Nothings the wealth of the Catholic church was being used to undermine American institutions. While this opinion had been held for some time events of 1853 and 1855 gave the know-Nothings further ceuse to criticize the Catholics. Eetween 1853 and 1855 a change in the status of church lands greatly increased the power of the bishop. By a decree of the Baltimore Council of Bishops all Catholic church property was conveyed to the bishop. By their decree one hundred million dollars worth of property in the United States, was placed in the hands of the Catholic Bishope. (44) The Louisville Daily Journal and other Know-Nothing organs construed this centralization of authority as another instance and proof of Catholic perfidy. The Catholics in Louisville saw in the organization of the knowNothing party an organization working to destroy the Catholic church. There were two principle charges the Catholies brought against the Know-Nothing order. First, the anti-Catholic movement had been started by disgruntled Whigs who were jealous of the strength of the Democratic party, to which most of the Catholics belonged. The Whigs repeatedly accused the Democrats and the Catholice of being undemocratic and unpatriotic, Know-Nothing sympathizers frequently laid the charge of political aggression at the door of the Catholic hierarchy. The Democratic press recalled that one of Kentucky"s great leaders had been Bishop Flaget, appointed as Bishop of Bardstown in 1808. To the charge that

(43) Ibid., July 22, 1855.

(44) Louisville Weokly Courier, quoted from Danville Tribune, April 7, 1855. I have found no other roference for this. 
Catholics were being favored in public offices in Louisville the Courier of fored proof that of one hundred persons in the public pay "the only Roman Catholla: aggressor on the city Treasury was one young lady teacher, accidentally olected by the Board of Education". (45) Despite the anti-Catholic utterances of the Know-Nothing party Bishop spaulding was of the optnion that many members were high-minded men motivated by sincere purposes. However, he thought that after growing in strength for some time, many undesirable elements had gradually taken control of party policies. Then, Bishop spaulding accused the intelligent members of the Know-Nothing party of playing on the "gullibility of the masses to advance their own thoroughly selfish purposes". (46) Many people in Loufsville were certainly very "gullible" rogarding the political activity of the Know-Nothings .

In addition to the charges of political ageression made against the Catholics, a far more serious point of controversy was the relicious. Tho Catholics charged that the guiding spirit back of the Know-Nothing movement in Louisville was the Louisville Protestant League. (47) According to: Bishop Spaulding this Protestant organization had banded together to expose "the abominations of the Papacy". (48)

Discrimination against Catholics holding office certainly existed in Louisville and caused Mr. Benjamin J. Tebb, the leading Catholic laymen in Louisville to say, "Catholics are not all fools.....they will be compelled for the sake of peace, to form communitios all their own in different parts of the country, where, having popular majorities, they will be forced into office..... Thus will be brought about the very state of things which members of the new organization effect so much to deprecite.". (49) In answer to the contention

(45) Tilson, Samuel, history of Kentucky, S. J. Clarke Publishing Company,

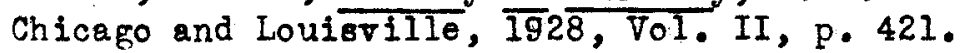

(46) Centenary of Catholioity in Kentucky, p. 483.

(47) Centenary of Catholicity in Kentucky, page 513.

(48) Ibid., p. 513 (No other reference to the Louisville Protestant League has been found by the author.)

(49) Ibid., p. 517. 
of Bishop Spaulding that Protestants rere trving to festroy Catholicism we have the Baptist view that for several reasons this or nization (Know-Nothing) was peculiarly repugnant to the Baptist churches...." Baptists have never been very favorable to secret societies even when they were purely social".... Religious proscription was "directly reougnant to one of their most cherished princioles. Wuch confusion and disorder prevailed among the churches during the prevalence of this Dolitical orcanization." (50)

Prior to the meeting of a know-Nothing convention in Louisville in February, 1855, support for the Ynow-Nothing cause was ohtained from a source th: th had been originally hitterly opoosed to know-nothinoism. In 1854 a campaign was conducted to organize the "Sont of Temoemance". On December 13 and 14, 1854, a convention of this lemperance organization met in louisville to nominate candidates for the state election of Aurust, 1855. Georse williams wa nominated for governor and James a. Hardy for lieutenant-oovernor. I check had heen sut on the temperance roverent "by the universal excitement conseruent upon the somation of a new bolitical art in the state." (5l) The temperance oreanization counted on the suport of the rnow-lothing ormization. "All the churches, save the Catholic, favor us, I believe, too, that the Know-Nothings will the up lir. Williams. In 1840, when a member of constitutional convention, he with Garret Lavis (prominent Know-liothing) asserted the true principles of Americanism". (52)

Referring apin to the hove of now-Nothine suboort another speaker sait, "No one expects the Democrats to favor us.....an essential Dart of its strencth is cormed of those foreign voters. Jur only hope is from the

(50) Snencer, J. E. History of Kentucky Raptists 1765-1885, N. P. Huthor 1886, pp. 714, 715 .

(51) Spencer, History of Kentucky zantists, p. 713.

(52) Speech of D. I. Sjear before the Ternemanconvention in Iclisville December 23, 1854, juoted in Louisville Neekly Courier, Decemher 2.3, 1854 . 
Whigs and the know-Nothings. I fear the higs for they imagne themselves in the Majority. As for these know-Nothings..... T have praved for their success. They and the Temperance neople must unite.... Who tipples chiefly? Foreigners. Tho mostly sells the accursed stuff? Foreioners." (53)

As the know-Nothing movement increased in imnortance the Ternerance movement decreased. Vr. Tames Fiady, Temnemane canditate for lieutenantrovernor, tis iso nominated $h \mathrm{v}$ the know-Nothincs for lieutenant-governor in their convention in February, 1955, "Nich great]y surnassed the Temperance convention in interest. (54) The Terperance groun gradully merred into tise Know-Nothing party as the issue hetween that party and the remocrats hecame more oronounced. (55)

At the sume time that the know-Nothines and the Democrats were preparinf for their convention the thios rere miking plans for their state nominating conventions to he held in touisville, fervery 22,1855 . The louisville Daily Journal recognized in the political sitution in Lonisville four distinct elements: Temperance, Know-Nothingism, Locofocism, an? Whigism. Interestinelv enough the Journal believed that the rix orincioles would remain distinct ant septrte from the princibles of the other porties--" then the Whigs of Kentucky meet in corvention--they :ill meet as hios, not as vainelawites or Know-Nothings". Sut, the hip convention did not meet. Deating the necessity of cuution in a "period of noliticn l transition lixe the oresent. when old arties, seem toppling to their $911 \ldots \ldots$ it bohooves the whig party... to act with the utmost prudence and iscretion." (56) A rival paper also wrote, exrly in Fehrury, 1855, of the orobable reeting of a whis convention

(53) Touisville deely Courier, December 23, 1854

(54) Soencer, History of Kentury antists, p. 713

(55) Conie 11 y and Coulter, 5.847

(56) Louisville Daily Journa I, Februtry 8, 1855 
"and a combination of Whigs rith each of the other parties of the state (not Demorrat)" (57) But the expected Wig corvention "ended in a Know-Nothing contention in Louisville and a hig assemblage....will only have to perform the mournful tuty of attenting the funeral of their old organization.... Farerell to the nme hig." The Democrats vere "not at all surpriset that the riries have rone into know-rothinoism." (58) The thigs hlamed their political wos on foreigners.

In Janury, 1855, the Ynow-Nothing, State Council was in session at the Lou isville Hotel. it least they were supposed to he in session, but hecause of the sforet nature of their actions, there is no definite statement about this meeting, certainly not while the meeting wa in session. accoring to the Louisville Neekly Courier, "ahout the only real information at the time was mere rumor. It is said by some that 'sam', a nime ferisively riven to the Know-Nothing party, is tarrying ith us a few fays. We haye ret a great many individuals suspected of close irtimacy with sam'.... nersons of this sort are cronding the town. Notice the hotel recisters ard you mill observe the names of many not wholly unknown to fame. These, it is imapined, gathored vesteray, accoring to abointment at odj pellows vall, where all the preliminarv exercises we re rad, such as arnointing president, secretarv, etc,.... "mone the speblers restertay were General Pilcher and the honorile Humphrey "arsall. The former had buriet the tomahawk of Locofocoism. Jomenody says, thourh rohoty of course knows, that the chief obiect of the present gathering is to fix up licket for Governoe and Lieutenart-Governor. Colonel J. S. Williams is favored for vovernor and Captain 4. C. Bullock is pavored for Liedtenant-Governor". The Courcil adiourned rithout mine anv nominations for

(57) Touisville Daily Democrat, Felmury 9, 1855

(58) Ibid., Fefruary $2 \overline{3,1855 .}$ 
officers. In this January meeting there was considerable difference of opinion and for that reason the meeting adjourned to meet in February. (59) The Council delegates had been nsarly divided in their views on gubernatorial candidates. About one-half of them favored J.S. Williams and John Hardy, the Temperance leadert ant the other half favored other candidates. The Louisville Weokly Courier expressed the opinion that Tillfams and Hardy would win easily over all the other candidates.

On Washington's birthday, 1855, the State know-Nothing convention met in Louisville. Among the candidates considered likely to win the nomination for Governor were Judge Williams V. Loving of Russellville, Judge Bullook of Louisville, and Judge Robertson of Lexington.

Finally Judge Loving won the nomination for Governor and James G. Hardy, a former Democrat, won the nomination for Lieutenant-lovernor . (60) The decision on the candidates for these two highest state offices was not at easy. There was considerable wrangling over the choice for state offices or as one newspaper said, ".they agreed to disagreo". (61) The reason fo $r$ this difference is not hard to find. The know-Nothing party certainly was not a harmonious group. Their organization was for reasons of expediency. Consequently, they found it difficult to agree on men for public office although they were all in substantial agreement with the party plafform. Many delegates: who had beon so long divided in sentiment were finding it very hard to unite. The Louisville Neekly Courier in commenting on the convention intimates that there was some difficulty in deciding on candidates when it said, "the knowNothing convention has at last hatched a governor". (62) Judge Loring soon resigned in favor of C.S. Morehead. The reason given for Judge Loring's rosignation was ill health.

(59) Louisville Weekly Courier, January 27, 1855.

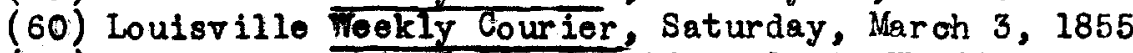

(6I) History of Ohionfalls Counties, L. A. Williams \& Company, 1882, Vol. I

(62) Louisville Woekly Courier, Mar oh 3, 1855 
Since one of the important principles of the Know-Nothing Party was secrey regardingtheir choice for public officials the knowledge of the choice for g vernor and lieutenant-governor caused some observers to say that Know-Nothingism was no longer secret but out in the open in the political campaign. Some even recognized the "Whig Party in disguise". (63) "Abolitionism and Know-Nothingism have taken it (the Whig Party) to their foul embrace and hugged it unto death. With their hideous:kisses they have stiffled its breath until it is as dead as death itself and can nover be resuscitated." (64) As wo have stated before, the whig Party was already dead so the above statement is important only because it shows the attitude of some of the opponents of the know-Nothing party.

(63) Yillis, p. 167 .

(64) Conneliy \& Coulter, Vol. 2, p. 846. 
CHEPTER III

THE SPRING EIECTIONS OF I 855 


\section{CHAPTER III}

\section{Spring Elections, 1855}

True to American party principles the support of that party for candidates in the municipal elections of April, 1855, were not revealed. The Know-Nothingparty pledged secrecy and that gave it considerable additional strength. According to the Louisville "Teekly Courier "Sam seems to be quite complacent and takes things very comfortably, whilo the anti-Know-llothings are holding meetings nightly and are fuming and fretting, and are kicking up pretty considerable of a fuss generally......Hundreds of persons in this city who sympathize with its objects and aims will vote for its nominees". (1) In the election the Demooratic organ called attention to the fact that heretofore major political parties did not nominate in local eloctions. Each man ran independently. (2)

Extra police were assigned by the mayor to vanous wards to insure an orderly election. No serious rioting occurred..... but "voters who wero not of the right sort, in the estimation of these patriots (Know-Nothings) were kept from voting effectually." (3)

The Know-Nothings succeeding in electing their candidate, John Earbee, mayor b a majority of 3,070 votes over James Speedi. James Speed was mayor of Loufsville at the time of the election and he had refused to run for rolelection, contending that his torm as mayor did not expire until 1865 . On May 9 Judge W. F. Bullook ruled that Mr. Speed was right and that he ou ld continue to serve as mayor. The Ciraid Court of Appeals later reversed:

(1) Louisville Weokly Courier, April 7, 1855

(2) Daily Democrat, Fobruary 17,1855

(3) Ibid, Apri? 9, 1855. 
Judge Bullook's ruling. The know-Nothing party already ontrolled all the other eity offices and the city employees were already regarding John Barbos as the legal mayor when the Circuit Court of Appeals made its ruling. (4)

The action taken bv the city administration in regard to the controversy over the election for mayor is recorded in the Journal of the General Council of the City of Louisville, as follows:

"Whereas, John Barbee was elected Mayor of the City of Louisville by the aurlified voters therof at the late genveral election held on the first Saturday in April, 1855, and a certificate of election has been awarded him by the General Council and he has taken the oath of office prescribed by the charter of ordinances of said city.....

"And whereas 2lso James $\mathrm{S}$. Speed, the late incumbent, in the office of Mayor of the City of Louisville has refused to deliver to the said Barbeo the Mayor's office,furniture, books and papers and the seal of the city and pretends that he is still the nayor of said city for the onsuing year and entitled to exercise the guthority and receive the emoluments of said office and it now becomes necessary for the General Council to estimate some rule of conduct in recognizing the authority of one or the other of the elaimants of said office. Therfore, be it resolved by the General Council of the City of Louisville that said Council will recognize John Barbee 28 Mayor of the City of Louisville for the term of two years from and after this date (April 30, 1855) or until his successor in office shall be elected and qualified and that said Barboo shall be entitlod to exercise the authority and receive the emoluments of said office.

"Resolved further that from and after this date said Council will neither receive from said speed any communication nor send to him for his approval any ordinances or resolutions nor in any other manner recognize him as Mayor.

"Resolves further that the Auditor, Treasurer, Clerks, and all other executive and ministerial officers of said city are hereby directed to recognize and respect said Farbee as Mayor of said city." (5)

"The Know-Nothings swept the city and elected their candidates

by large majorities." (6)

The election gave very good signs of what could be expected in the state election of August 1855, both as to the strength of the Know-ivothing party and the possibility of conflict betweon the know-Nothings and the for-

(5) Joint Resolution of the General Council of the City of Louisville, May 2,1855 .

(4) Collins, Richard H., History of Kentucky, Collins \& Company, Covington, Kentucky, 1882, Vol. F., p.74

(6) Louisville Weekly Courier, April 14, 1855. 
oign, anti-Know-Nothing element. A Demooratic sympathizer saw in the April election $2 n$ indication that violence would be used in order to defeat the Democrats in the August elections. The vote in the second and the eighth wards was particularly large "confirming the charge that the polls in those wards were under the complete control of mob law," (7) meaning the Know-Nothing party.

The Courier also pointed out that "the election will prove incontestably that Kentucky soil is peouliarly adopted for the vigorous and permanent growth of true American principles." (8)

According to the Louisville Daily Journal further clained that native Americans had been intimidated at the polls and "barred from voting by a formidable rush or pressure from foreign-born citizens". (10)

The Louisville Weakly Courier at this time was following the most unprejudiced course in the controversy over Know-Nothingism. Consequently its account of the election is probably more trustworthy than that of the other Louisville newpapers. The gist of the Couriex's comments are to the effect that the Know-Nothings, an "American" party, had conducted themselves in an un-American way. A German military unit had been given a cannon to care for before election day and this had aroused some native Americans to such an extent that they proceeded to try to take the cannon away from the German unit. As a result one man was killed and several were wounded. (11) This was one of the preliminary incidents of election day. Then in answer to the charge made by the Louisville Daily Journal that an unusual number of foreigners were being naturalized pre-

(7) Louisvill Weekly Courier, April 14, 1855.

(8) Ibid.,

(9) Louisville Daily Journal, May 7, 1855

(10) Louisville Teekry Journal , May u, 1855

(11) Ibid., Apri 7, 1855 
paratory to their voting on election day the Courier replied that "during the past month not over twenty-five had been naturalized." (12) In fact a growing apathy among the foreign element in Louisville had been noticed as the know-Nothing party become more aggressive.

The following report by the Courier of the election day disturbances gives a fairly accurate, unbiased account:

"The first ward polls was the principle theatre for the display of intemperate order on the part of anti-Americans. A report was circulated that the Sag-Niahts (anti-Americans) weregoing to take charge of the polls. This started a counter move on the part of the American party. All day long foreigners and Americans were milling around the polls. Trouble was started by each side thinking the other side was trying to prevent their votes. The foreigners had a preponderance in numbers but the Americans had the advantage in will and muscle. Both were trying to vote and fight but this became weariscme, fighting being substituted for voting. Members of each side actively participated in roting and fighting." (13)

The Louisville weekly Courier fairly takes the "inconsiderate friends of Americanism" to task, "innocent foreigners on the street and in their own homes were beaten unmercifully.....the houses of some Germans were ontered and their property destroyed". (14) The Louisville "leekly Courier concludes, however, that many of these outrages were provoked and that' both parties were a bout equally to blame.

Before taking up the events in Louisville connected with "Bloody Monday" two very significant events were happening in the nation that deserve some mention. First, the state election in Virglnia, in which Henry A. Wise, a Democrat, defeated Florney, the know-Nothing candidate, in the race for the governorship, is important because this election really showed the great weaknoss of the Know-Nothing position. Second, the Know-Nothing convention which met at Philadelphia, split on the slavery issue. The weaknessof the know-Nothing movement was clearly shown by these two events and for that reason they de-

(12) Ibid.

(13) Louisvillo Meokly Courier, May 12, 1855

(14) Ibidi. 
serve brief mention.

In Virginia, the first state election of the year, Henry A. Wise, the Democratic candidate for governor was opposed by a man named Florney, the Know-ilothing candidate. "The Thigs of Virginia flatter themselves that they will defeat Henry A. Wise.....To accomplish this they have abandoned the notion of a "hig convention and handed over their effects to the Know-Nothings." (1 Onfortunately for the know-Nothing cause Florney made the mistake of bringing the Catholic question into the campaign and, since the sentiment of the South was not particularly opposed to Catholicism, this action took some of the strength from the know-Nothing cause. "Tise made a vigorous campaign," succoeded in fixing upon know-lothingism the imputation of intolerance and of prescriting a religious test as a qualification for office", (16) and defeated Florney by a 10,000 maiority. (17) The know-Nothing party, over-confident in this camprign, did not take the stump actively in Florney's cause and did not successfully refute Wise's charges. The "Basic Principles of the American Party in.Virginia" made no mention of Catrolics but favored relifious toleration. (18)

There are two significant conclusions to be draw from the Virginis Compaign. First, slavery was the real issue before the country and not Catholicism. The Southern states could hot be aroused over the dangers of "Popery". Second, the Know-Nothing principles eailed to attract Democratic votes. A majority of 10,000 was a "usual Democratic mejority" . (19) These two brief conclusions are, of course, closely related; one lends significance

(15) Daily Democrat, February 7,1855

(16) Cole, A. C., Whig Party in the South, p. 318

(17) Rhodes, History of United States from Compromise of 1850 to the final Restoration of home Rule at the South in 1877, New York, MacMillan Company, 1910 p. 88.

(18) Cole, A. O., Mhig Party in the South, p. 317

(19) Ibid:, p. 318 
to the other.

A though the Democratic party in Virrinia had decisively defested the know-Nothinos this fact was not accepted hy all as the end of the knowNothing Party. With this election out of the wy the next election of rreat interest was in Kentucy. Victory was predicted for the Americh ourty by the St. Ionis Intelligencer in the following worts: "It takes the thoroughgoirg, amhitious, mpassioned, patriotic, office-loving, eloguent and heels-over-tead kentucky politirians to to fustice to such an institution as te american narty, and they are doing it." (20)

The second important political event in the sumer of 1855 was the Know-Nothing convention in Piladelphia in June. Ediard B. Bartlett of Covington, Kentucky, elected president of the convention. Bartlett was a former Democrat and according to the Louisville leckly Courier, a slave owner. Eis selection was termed a "damned Massachusetts trick". (?1) hy Yentucky Know-Nothings, because in some quarters Bartlett was consitered an aholitionist.

The great question before the convention was that of slavery. The resolutions committee submitted a mainity report which reommentef that Congress maintain the evistino laws on slavery and further stated that Congress ought not, to orohihit slavery in any territory or in the District of columbia. The nlatform contining this famous twelfth section was adontes hy fourteen Southem stats: the states of New York, District of Columbia, Tenneessee, and Yinnesots. Raynor of North Carolina suggested that all reference to slavery be stricken out. His motion was defested, 80 to 59 , and the national Know-Nothing party was snlit, Henry Wilson of Massachusetts leading twelve northern states from the convention. Following the conention at least scven Northern states

(20) Cuoted in the Louisville Weekly Courier, June 9,1955

(21) Louisville Weekly Courier, June $\overline{16,1955}$ 
and a number of Southern states drew up party platforms. Obviously the party had split. As the Louisville Weekly Courier so aptly stated, "the question now is 'Sambo' instead of 'Sam' and "Africa' instead of 'America'. " (22) On July 8,1855 , the Know-Nothing party in Louisville met to ratify the action taken at the National Convention in Philadelphia. Opinion in Louisvilie was rather divided on the merits of the plotform. The Louisville Daily Democrat pronounced the platform as unsound but the Louisville Daily Journal, the Know-Nothing organ, after deploring the slavery plank, "the stolen creed of Democracy", said, "The sound and noble principles of the Philadelphia convention will soon carry everything before them even at the North, if Kentucky, Tennessee, and other gouthern states shall succeed in maintaining them in the great conflict near at hand". (2.3)

Ward delegations of the Know-Nothing party met in the Courthouse square to ratify the national know-liothing platform. A group of German Republicans, pro-American, carried a large banner to the mass meeting bearing the words, "We came here to live, not to rule." Enthusiastic speakers addressed the crowd from either end of the speakers platform and the meeting adopted the following resolution:

"That this meeting approve, ratify, and confirm the doctrines and principles of said platform as the best national ground on which we and every true American can stand for the safety and the perpetuity of the Union and to secure the blessings of liberty to ourselves and our posterity." (24)

The Louisville Daily Journal applauded the "ratification of the Second Declaration of Independence, the platform of the American party".(25)

(22) Ibid., Iune 23, 1855.

(23) Louisville Daily Jaurnal, July 25, 1855

(24) Louisville Daily Journal, July 5, 1855

(25) Itid. 
CLMPTER IV

THF ELFCTON OF ATGUST 6, 1855 - "3IOODY NOMDAY" 
CHAPTER IV

Eloction of meust 6,1855 - "Bloody Vonday"

While the National Convention was going on and the ratificrtion of the convention platform wa taing place in Louisville the local political parties vere berfecting their organizations preoratory to takino nart in the August ejections. The Know-Nothinf garty wather confident. The leaders in Iouisville looke format to the Aurust eleotions, helieving that "the Ides of Wreh will work wonders in Kentucky". (1) The know-Nothing leaders believed that the party met a real need better than the defunct inig party in that it found leaders "in men who were open to conviction.

A number of Know-Nothine Councils organized in Louisville formed the nucleus of the nativist political organization. A list of some of these councils ant their slogans follows:

1. Jackson Council, "gy the eternal, the Union must and shall be oreserved."

2. Young imericin Council, "Ne emulate the virtues of our sires."

3. Jefferson Council, "The orice of liberty is eternal vigilance."

Other Know-Nothing Councils rere the Mshington, Falls City, Union, Boone, Billines, and Liherty. (2)

Almost from the herinning of the Know-Nothing onty an oposition party had existed. The Louisville oroanization was piven the nickname of the Sag-Nichts by its opponents. The charge made freruently against Know-Nothines, that of secrecy, could iust as fairly he mate arainst the sar-Nichts.

(1) Louisville Neekly Courier, June 13,1855

(2) Louisville Daily Journa I, July 3, 1855 
The Sag Nichts, composed principally of foreigrers were organized into squads of approximately ten each, having a commander/was responsible for their presence at meetings. The Louisville Democrat acknowledged the existence of the Sag Wicht organization but insisted that they were merely aids to the Democratic party and not integral parts of the party organization. The Louisville Times maintained, however, that the Sag Nichts included the whole of the emocratic party. The Louisville Neekly Courierestimated that the Sag Nicht organization had a mombership of about $2,000--"$ this is about the strength of the whole anti-American organization in Louisville." (3)

In addition to the Sag Nichts a national Democratic organization known as the Democratic Association, had been forming for the purpose of defeating the know-Nothings. The Louisville weekly Courier considered this the best of the Democratic organizations and warned the Know-Nothing organization in Louisville against being over-confident. The Democratic As cociation was formed to aid the Sag Nichts although it was separate and distinct from that organization. (4) The Louisville Daily Journal considered the SaE Nichts to be a gang of toughs and the Democratic Association to be for the purpose of appealing to a better class of Democratic voters. (5)

The race for governor was between Charles S. Morehead, the KnowNothing candidate, and Beverley Clark, the Democratic candidate. Worehead, as stated above, was a substitute candidate for Filliam V. Loting, who declined to enter the race because of poor health. Morehead was accoptable to most of the Know-Nothings in Kentucky although he had been known as an anti-nativist a few years before tris nomination. (6) Morehead was born in Nelson county in 1802, had

(3) Louisville "'eekly Courier, April 27, 1855.

(4) Louisville Daily Journal, June 24, 1855

(5) Ibid., July $4,18 \overline{8}$

(6) Louisville Meekly Courier, January 13, 1855 
served his state in the legislature and as Attorney General, and had also been a member of Congress. He had been a close friend of Henry Clay and a co-worker with him for the Compromise of 1850 . On the whole, he was a very able candidate, one certainly capable of winning many know-lothing rotes and also many votes from those who still were clinging to their "Whiggery". James G. Hardy was the Know-Nothing candicate for lieutenant-governor, James Harlan, Attorney General, and R. C. Wintersith, Treasurer.

Both liumphrey Marsha11, the Know-Nothing candidate for Congress from the Louisville district, and Villiam Preston, had distinquished records of public service. William Preston was born near Louisville in 1816, the son of Tilliam Freston, an officer under Ceneral Anthony Wayne. Preston was a so ldier in the Mexican war and served with distinction. In 1849 began his real period of public service when he was made a delegate to the constitutional convention. From 1850 to 1852 he served 28 member of the House of Representatives and in 1852 he took Humphrey Marshall's place as a Thig member of Congress when Marshall went to China as minister. When the phig party broke, Preston joined tho Democratic party and in 1858 he was appointed minicter to Spain. When the Civil War came Preston threw his lot with the South, was exiled but permitted to return to Lexington in 1866. In 1860 and 1869 he again served a member in the House of Representatives, this time from Fayette County. (7)

The Louisville Daily Journal quotes the following from Daniel Webster regarding Humphrey Marshall: "Humphrey Marshall is an able man, a very able man; I have heard him upon two occasions and 1 regard his ability of the highest order. I consider Humphrey Marshall at this moment the greatest man of his age in the United States".(8) The contest in Louisville was not only one of principles but also one of outstanding personalities, both with enviable

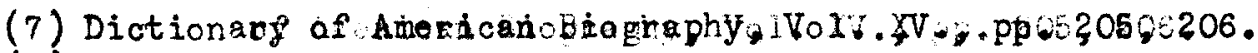

(8) Louisville Daily Journal, June 19, 1855. 
records as public servints. Marshall had been minister to China under Fillaore. For sometimes prior to the election there was considerable excitement and a growing spirit of hatred between the two parties. By July 28, 1855, the Weekly Courier could say "many persons will fight at the drop of the hat." (9)

The fitter feeling that existed in Louisville prior to election day may be judged by the tone of the editorials. The nowspapers were eager to prevent any form of disturbance but they were more eager to arouse their own particular party members. In the appeal to the emotions and not to the intellect the Know-Nothing organ had a decided advantage. Their comments could be colored, 211 sorts of insinuations could be hurled at the Catholic charch and foreign organizations and about the only reply from the Democratic organ was a denial. This lacked the sensational appeal of the Know-Nothing organs. Yost of the following excerpts are taken from the Louisville Daily Journal, but they give a very accurate description of the feeling prior to election day. Also these quotations show the extreme views of George D. Prentice, editor of the Journal, who later blamed for much of the trouble occuring on Bloody Monday.

1. Quoting from Innocent III: "It is necessary for salvation for everyone to be subject to the homan pontiff." (10)

2. Reference to Catholicism: "..... doctrine that places the supreme political sovereignty of America in the Roman pontiff instead of the American peoplo." (11)

3. "The Louisville Democrat itself and the rest of the anti-American organs have been working desperately for many months to create the impression that the members of the American party are violently enraged against the foreigners and desirous of crushing thom in the dust or driving them out of the country." (12)

(9) Louisville Teekly Courier, Saturday, July 28, 1855

(10) Louisville Daily Journel, July 3, 1855

(11) Ibid.

(12) Ibid., July 10, 1855. 
4. "Another anti-American candidate proclaimed that the Germans and Irish shall vote even at the cost of a fight half a mile long." (13)

5. "Until the light of Protestantism shone in the world there was no religious freedom."

6. "Let the foreigners keep their elbows to themselves today at the polls. There's no place for them in the ribs of natives..... They (Know-Nothings) may have to encounter fire and steel but they will vote."

7. "Fellow-citizens, shall the shouts of triumph that echo through our streets tonicht, be raised by American voices or shall they resound in the harsh tones of Ireland and Cermany?"(14)

It is significant, in view of the abov statenents, that very few articles of incendiary nature was printed in the Democratic organ, the Louisville Daily Democrat.

One sugcestion made in the Louisville Daily Journal deserves special attention. As early as August, 1854, the voters of Louisvillo had been handicapped by not having a sufficient number of polling places. Referring to the election of August, 1854 the Know-Nothing organ had said, "We cannot but think that a grievous wrong was done to the citizens of Louisville by the failure of the General Council to multiply the number of polling places in each ward. The result of the election shows that a large number of voters in Louisville were cut off rom the privilege of voting." (15) So, in the summer of 1855 the question of having enough polling places came up again. Prentice met the situation $b y$ suggesting that in all cases naturalized citizens should stand aside and wait until the native vote had been counted. A longer time to rote was usually tak $\rightarrow . k$ naturalized citizens than native citizens and Prentice used this as one reason for allowing the native vote to be cast first. ( 1 Considerable buying party support was evidenced by the accusing newspaperarticles that appeared during the month of July, 1855. The Louisville

(13) Louisville Daily Jounna

(14) Louisville Daily Journal, August 6, 1855

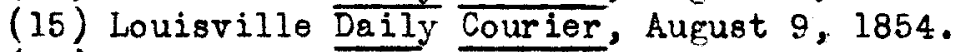

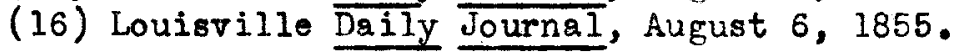


Daily Journal maintained that "more than 800 active and influential anti-Americans in this Congressional District, all paid for their time, are making the work of electioneering and organization the business of their lines.....The most important Sag-Nicht agency in this canvass is that of money."(17) "he Democratic Associations require members to pay a fifty-cent foe, and others ou voluntary or forced subscription contributed to the Anti-know-Nothing funds. "The Anti's have more money than in any other district in the state. It (meaning anti-Americans) has more than miltary rigor and precision." (18) Captains were placed over every five (5) anti-Know*Nothings and he was responsible for six votes. An agent works on every five doubtful voters offering to purchase votes of those Americans whoso principles are not inflexiablo. At every antiKnow-liothing council meeting a report was made of the progress in dealing with this doubtful element. A letter from Frankfort, quoted in the Louisville Daily Journal said that "every species of trickery is being resorted to by the anti-American party to defeat us in August. Our friends must so organize as not only to be able to cast their utmost strength at the polls but to mark and exclude every fraudulent voter." (19)

The pre-election activities of Bloody honday did not stop with editorials. Actual threats of violence were uttered and a number of actual clashes preceded the climax Bloody Monday. The Louisville Daily Journal says it has been accused of being "violently enraged against the foreigners and desirous of crushing them in the dust or driving them out of the country. Te have no doubt that the anti-American leaders and demagogues would hastily rejoice at the prospect of a collision between the two parties in August." (20)

(17) Louisgille Daily Journal, July 17, 1855.

(18) Ibid.

(19) Ibid., July 27, 1855

(20) Ibid., July 12, 1855. 
"The incendiary harangues and conditional threats of the anti-American leaders are well-calculated to prepare men's minds for scenes of fearful violence." (2I) The editor of the Louisville Daily Journal learnod that a very muscular man of the Lower Fonds district had been offered a large sum of money by the anti-Know-llothings to take a stand at the First ward polis on election day. "In all earnestress we appeal to the influential men of both parties not to anticipate any outrage, any violence of the rights of freemen, and not to dream of such nadness as arming with deadly weapons for the election." (22)

While most of the editorials were incendiary the newppapers. also professed their desire for an election free from fighting. The attempt was made to have the election in a single day and so unusual precautionary measures were recommended. One of the most reasonable requests was for two or more polling places in each ward. According to the city charter only "one voting place for each ward could be established and no aseistant clerks could be appointed". (23) The Democratic organization in Louisville had insisted on two or more voting places in each ward but the city Council "made it utterly impossinle to poll the entire rote in the First, Second, and Eighth wards." (24) "This is the last trump card of a great party." (25) This same opinion was expressed more fully in the Daily Democrat.

"Wo wish the public abroad to understand how a Know-Nothing Council, and Know-liothing authorities here generally, provide to carry the ensuing election. There are about 1,400 voters in the First ward and we. to have but one place of voting, one clerk to record the names. He cannot get through more than half of these votes between the hours of 6 a. $m$. and $7 \mathrm{p}$. $m$. .....To accomplish the work effectually the polls are to be taken by the know-

(21) Ibid.

(22) Louisville Daily Journal, July 18, 1855

(23) This is, of course, Know-ivothing interpretation of the Charter

(24) Louisville Teekly Courier, July 30, 1855

(25) Ibid., August $11, \frac{1}{1855}$ 
Nothing party until all their votes are polled..... In this way an oath-bound, socret organization is to suppress the voices of a majority." (26)

Judge Garland of the Jefferson County Circuit Court appointed 32 election officers for the August elections. Polling places for the eleotion had been designated in each ward by the city Council. According to an older law the election was to be controlled by a judge representing each political party - A know-Nothing judge and a Bag-Nicht judge would properly have officiated at this election. Of the thirty-two men appointed, both judges and clerks, twenty-eight of them were reported to be know-Nothings. The Louisville Daily Journal' boasted of this. According to the Louisville Daily Democrat, only "three ov four of the thirty-two election officials" were Democrats or anti-Know-Nothings. (27) The Louisville Weekly Courier also pointed out that "Judge Garland had refused to appoint swift and competent clerks who, were recommended to him". (28) Whether this is true or not, it is probably true that the majority of election officials were know-Nothings.

Many citizens had already anticipated that an unusually largo police force would te needed on election day and the know-Nothing organ suggested that the "police force, being inadequate, the fmerican party vould appoint a sufficiently strong man from their own orcier and also asked that its aid be accepted by the city authorities". (29) The Louisville Daily Journal was informed that the mayor had already adopted a policy of appointing an aditional police foroe "without regard to party." (30)

This was a policy frequently followed at election tive. The appointments were of course temporary. (31) In the election of August 6,1855 ,

(26) Louisville Daily Democrat, July 31, 1855, (Votine. was a slow process since all naturalized citizens were recuired to present proof of their citizenship.)

(27) Louisville Daily Democrat, August 1, 1855.

(28) Louisville Teekly Courier, August 11, 1855.

(29) Louisville Daily JournaI, July 24, 1855.

(30) Ibid.

(31) See Joint Resolutions of the General Council of the Cityr of Iouisville, April 5, 1855. 
there were fifty additional policemen appointed to aid in the safe conduct of the election. (32) This made a total of eichty policemen. (33)

As election day approached excitement swelled and events of the preceding week gave ample evidence that the election would be hotly contested. Before election day riots occurred in various parts of the city. Houses belonging to foreigners were damaged, unoffending citizens were attacked on the street, and a Catholic church where firearme were supposed to have been stored was visited. Violence and street fights were nightly occurrences. On Saturday night preceding election day a gunsmith of Louisville said that he had cleaned and put in order over two hundred guns for the Irish living in that neighborhood. Also a large quantity of ammition had been stored in some houses on flain Street belonging to foreigners. According to the Louisville Daily Journal, the Daily Dethocrat says, 'thet we and our sworn brothers have taken an oath not to appear at the polls with knives and pistols and brass knuckles. We certainly mean to keep that oath. We have not the least thought of breaking it. "(34)

A "Nilliam R. O"Brien reputedly "a violent Sag Nicht bully" at. tacked a Mr. Keller Saturday night on Preston Street, near Green. This, according to the Louisville Daily Journal is a sample of the "violence nightly atternpted and continually contemplated by bullies of the Sag Nicht party". The next day the Louisville Daily Journal carried an apology for the above stateruent, having found out that Keller had attacked O'Brien and not vice versa. This detracts somewhat from the story of the Sag-Nichts bully, $0^{\prime}$ Brien. The Louisville Daily Journal accused a Mr. James Weriwether of

(32) Daily Democrat, August 18, 1355

(33) Not until after the second charter were the law enforcement officers in Louisville called "policemen". Prior to that time thoy were called "watchmen".

(34) Louisville Daily Journal, July 14, 1855.

(35) Ibid., July $\overline{23}, 1855$. 
saying that "either he had subscribed or he would subscribe fifty $(\$ 50.00)$ dollars to arm the Germans ant the Irish of Louisville with knives and Distols on election day". (36) Veriwether denies this in the saturday paper.

Riots in the lower part of the town occurred huring the week of Friday, July 20, 1855. Tro people wer shot near Chane? and Min Streets; a Virs. Lee, and Mr. Stephen Alford who was shot in the arm. Wwo houses belonging to Irishmen vere stoned, one in the alley hetween loth and 11th, and Narket and Jefferson, and the other in the allev hetween 1?th and 13 th, and Varket and Jeferson. (37)

On Sunlay nioht the "Imerican fxecutive Comittee" went to the polling nlaces to see that the nolls were nronerly onened. According to the Louisville kekly Courier this committee vent "with the requisite refreshment". (38) This probably meant weaoons for use against the anti-know-Nothings. "By dapbreal the polls sere taken control of by the merican party.... we comment them forevor to the admiration of outlaws." (39)

bonlay, fupust 6,1855 , is one of the blackest days in Lonisville's history. Bad blood on hoth sides, ageravated and intensifict for several days nrevious by distorted representations of nreparation for serious work, culminated in a terrible an most discree ul riot. Before the close of this sad day in Lonisville's history a little boy was to see from his darkened window the sey arlow with the light of fires kindlet in the course of this bloody affray. This hov, now a man, reca'led the excesses ant hatreds of "Bloody Vorday" to the writer and some of is ohservations on this affair appear in the following story of that unlemocratic election tav.

(36) Louisville Daily Journal, July $14,1855$.

(37) Ibid., Fridgy, July 7, I855

(38) Louisville Weekly Courier, Aurust 11,1855

(39) Ibid. 
For the most part the roting iround the polls mas ouiet and orderly; only in the area say from the polline places tid any riolence t:ke olace and not ther until late ir the liy when excitement over eloction meturns reanhet its hiohest point. is stated above, very early in the doy the American Brecutive Comittee had the polling places under ontrol and no doubt they made full use of this advantage. All nerspapers are more or less agreed that the polling places were in the possession of the KnowTothine party. This fact is sufficiert to shor thit the know-mothings intendet to control the elections and that they dere rot ezpeatuly concerned with having a fair election. By mid-afternoon, when the riolenco started, the imfrican party had polles a very lare vole but after the beoinring of hostilities all thought of voting ceased.

At the first, fourtr, and sixth warts there was some $\forall i o l e n c e$. lccording to the Louisville Daily Journal, the Democrats Nere heavily armed, the foreigners having been led to believe by pirty learers that the imerican party was seeking to interfere with their vested rights. At the fourtr ward rolls the American marty had some difficulty in comtrolline the coreicrers, hut they succeeded in not permitting a single foreigner to votf. The touisyile Daily Journal wrote that in some polling places, particularly in the second ward "it was impossible for "mericans to vots" so completely had the Germans captured the pol]s. Other newspapers do not refer to the tisarimintion against the Know-vothings at any of the polling olares. An onserver of some of the incidents and carcel student of American History, Mr. Temple Bodley, who was for miny years a oromirent Louisville attornev, tolf the writer that the Know-Nothing party virtually controllet every poiling place.

More serious riots occurred in the upper wards. "The vote cast was $a$ political one and nearly 911 on one side. No show was given to the friends of Prestor who were in the majority, but who in the face of carnon, muskets, revolvers, could not, being an unarmed and quiet populace, con- 
front the mad mob". (40)

The sixth ward, one of the quietest and generally the most peaceful, was the scene of some of the worst excesses of "Bloody Honday". In fact this polling place was the only one in which there was any unusual degree of disorder. "There was no opportunity for fighting since the Know-Nothings had control of all the polling places. Every possible obstruction wa thrown in the way of those voting, who were not recognized as know-liothings. Large crowds were stationed at the entrence to shove back the freston voters while side and back doors were provided for Marshall pien." In the sixth ward "foreigners were driven from the polls and then beaten." One anti-know-liothing sympathizer says: "we saw two foreigners driven from the polls, forced to run a guantlet, beat unmercifully, stoned and stabied. "(41)

Late in the afternoon in the sixth ward, an Irishman was walking in front of the courthouse when he was assaulted by a gang of men each armed with a small stick loaded with legd. He was knocked down and brutally beaten and one man actually thrust a big pitchfork into the body of the unfortunate Irishman. The crowd proceeded to march the staggering Irishman to the jail. His assailant marched in the crowd "with the pitchfork on his shoulder, blood dripping from its prongs." (42)

In the morning a general row took place on Shelb Street extending 211 the way from ifa in Street to broadway. In this general encounter fourteen or fifteen men were shot, among them feorge Eerg, a carpenter. About 11 a. m. on the corner of Shelby and Green streets a severe encounter occurred involving native Americans, Irishmen, and Germans. Peace was partially restored

(40) Louisville feekly Courier, August 11, 1855.

(41) Louisville Weekly Courier, August 11, 1855.

(42) Louisville Teekly Courier, August 11, 1855 (This scene was also witnessed by James speed, former mayor of Louisville, See umes Speed, A Personality.) 
in this section when a cannon, fully manned, and followed by fifty military men armed with muskets came up the street. Defore order was established, however, the aroused moi had entered peaceful German houses and had done much damage. tany business houses, breweries, bakeries and groceries were destroyed. "A handful of foreigners mad à determined stand against the cowardly rioters end who were far superior to them in rumers." (43)

One notable event of'Bloody Monday' was the sttack on several Catbolic churches. For severaldas prior to election day,rumors that the Catholics had weapons concealed in the basenent of their churches had caused considerale excitement anong the know-ilothines. On election day several Catholic Clurches were entered and several were in danger of being destroyed $t_{y}$ the know-Nothings. One Catholic priest, pastor of a church on Thirteenth Street, had, prior to election day, asked that the know-Nothings enter his church and see for themselves if any guns were concealed in the basement of his church. Some Americans did enter and found nothing. (44) This occured before election day. Such ruinors as mentioned above almost caused the destruction of a Catholic church located at Fifth and Green Streets and another church, lccated on Shelby Street, only escaped destruction by the timely intervention of Magror Earbee and Marshall ridd who "hearing of the contemplated attack, arrived on the spot in tire. They entreated the rable to disperse and were told that there were cuns and mmmition and Cermans in the ohurch. "ayor carbee and liarshall Kidd went in, examined the church and found notning at al1--so reported to the mob ard entreated them to go home. Still refusing, hay or Larbee threatened to call out the militia."

Then fayor sarbee ordered the crowd, "under the command of Captau n Rousseau," (46) to retire.

(43) Louisvilie Teekly Courier, August 11, 1855. (44) Louisville Daily Journal, July 20, 1855

(45) Daily Democrat, Aug ast 8, 1855

(40) Louisville "eekly Courier, August 11, 1855. 
Defore taking up the most horrible phase of this election day

the following cxcerpt from a letter from James A. Speed to a man named Thompson eives an interesting account of the dars activities. Mr. Speed, former mayor and an eye-witness to much violence of "bloody Monday", went to vote before breakfast. At that time he said, "there was a good deal of noise and much yelling for Harshall". (47) After ilr. Speed had votod and had his breakfast, he went downtown to the courtroom where the votes were being taken and remained there until about nine or ten o'clock, The following quotation is from Mr. Speed's letter:

"Whilst there I heard the noise of several fights in the passageway and saw from the window Irishmen and Germans beaten and chased from the courthouse yard. Then I caine from the courtroom or the room in which the votes were taken in the passage, the crowd which had been in the passage had chased some foreigners into the yard east of the courthouse. I went to the east door of the courthouse and saw the crowd running down Sixth street. From my office I saw many men, Irishmen and Germans, beaten in the courthouse before dinner. It was not fighting man to man, but as many as could would fall upon a single Irishman or German and beat him with sticks or short clubs. From the time I came out of the courthouse till dinner time the courthouse yard was occupied by a number of men and boys armed with short clubs shouting, "Hurrah for Marshall! Hurrah for Sam!" They wore yellow tickets in their hats or on their breasts. Soon after I returned from dinner, about half-past two p. m. I saw a number of boys and men coming out of the courthouse armed with muskets and a great many armed with clubs. I inquired of Judge Badley what it meant; he replied that the Germans, two hundred strorg and armed with double-barrelled shotguns, had taken possession of the polls in the first ward. I told him it was not so and could not be so. He replied with warmth showing that he believed it to be true.

"I was about my office till about 5 o"clock. Before I left the office or the neighborhood, I saw many Irishmen carried to jail covered with blood."

Mr. Speed then tells about how a crowd of know-rothing bullies

pursued a little German up Jefferson Street.

"He fled into the courthouse yard and hid under the Know-ivothing speakers stand. They drageed him from the stand nore dead than alive and carried him to jail on their shoulders.

"I know that the courthouse and courthouse yard was in the possession of

(47) James Speed; Janes Speed, A Personality, Louisville, Kentucky; ilorton, 1914, pege 39. 
and under control of know-Nothing bullies from nine o'clock till night or until the foreigners were so frightened they would not come about there.

"I saw no foreigner misbehave or say any insolent thing.

"Wile I was in the courtroom I heard that the Honorable Will P. Thomason was struck when ttempting to save an Irishman. I saw ir. Thomasson soon after and saw the wound or bruise on his cheek. Fe told me that he had been struck for trying to keep the mob off of an Irishman they were pursuing." (48)

As was mentioned above, a great deal of the trouble on "Bloody Monday" was caused b' nischief makers sprading rumors. "Reckless rouths, who had been active in these things, spoke of their deeds in terms of levity that were shocking. They said that they did not know how many they had killed but that they had popped down every Irishman they saw. Whut itudes of half-grown boys, rendered perfectly devilish with ungoverned passion and whiskey, filled the streets with yells and violence. Christian men and women alike, becoming demons, urged on the young men. Most painful sights were witnessed. Poor women werefleeing with their children and little menentos of home that were brought from the Fatherland. The most painful of all sights was the stars and stripes waved at the head of the sacrilegious mobites." (49).

The above description is vivid but is probably slightly overdrawn. Some of the words used are entirely too loose. However, we must accept the fact that in a measure, the know-Nothings were really beyond control. (50) Wost of the blame for the damage done by milling mos must be placed on the socalled American party. (51)

The most horrible phase of "Bloody Monday" occured late in the afternoon on the north side of wia street, exst of Eleventh. The beginning of this awful incident is vididly told in the reminiscences of Wr. A. J. Webster

(48) James Speed, A Personality, p. 40-42.

(49) Louisville "ie $\bar{k}$ ly Courier, hugust 11, 1855.

(50) Just as today communist-baiting can arouse certain elements so the antiforeign and anti-Catholic movement appealed to the passinns of people who neither understood the foreigners or the Catholics

(51) This is the opinion of Mr. Temple Bodley who recalled some of the incidents of "Bloody Monday" to the author. 
of Boston, Massachusetts: (52)

"I was at "Pashington Engine: louse, a polling place, when a man came galloping up Jefferson Street whipping. his horse with his hat and shouting at the top of his voice.... This was the news he carried: "The First Engineer of the Henderson Packet, who had just completed his run, was on his way to his home walking auietly along llain street opposite tre "Quinn's Row" of buildings, when he was fired upon and mortally wounded." (It was afterward said this man was mistaken for another person.) The excitement was intense, nearly every man had a gun or some other weapon. The firebells rang and the Fire Department from all over the city sped to the sene. In the forces in 'Quinn's Row' had command af the situation. They completely covered the neighborhood of Twelfth and Main Streets and shot at any one who came within range. After a time a sharpshooter, armed with a long barrelled rifle, impoovised some protection for himself, and from the corner of Twelfth and Main streets shot and killed two of the alleged leaders of the forces in the 'Quinn Buildings'--who, so it developed, had there secret society's club room and a well-stocked arsenal. Neanwhile some adventurous lads had crawled along close to the front of the buildings, broke open the doors and set fire to the lower floors. After the fire started, the fire department began to put it out, but the firemen were quickly told that 'if you attempt to throw a drop of water on these buildings, we will cut your hose into ribbons, but you may protect the surrounding buildings'..... This it did. With the setting on fire to all the lower floors, the upper ones became untenable, and a panic and break for the outlets ensued. This was resisted by the mob and a battle royal took place in which a number of men were killed, among them father John Quinn."

The account given in the newspapers of the beginning of the riots

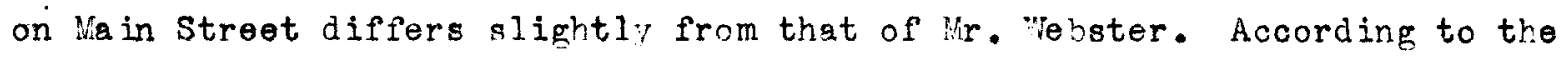
Louisville Weekly Courier the trouble started when some Irishmen and Know-Nothings got into fight in this neighborhood. The Louisville Daily Journal quotes a statement from a New York man who was in Louisville on election day and saw some Irishmen fire on two men near "Quinn's Row." (53)

The Irish were apparently well fortified in the houses along : in Street between Eleventh and Twelfth, and for a time resisted the efforts of the Americans to dislodge then. Numerous shots were fired by the foreigners from windows in some of the buildings, which killed or wounded Americans in

(52) Webster, A. J., Louisville in the $1850^{\prime} \mathrm{s}$, Filson Club Historical Quarterly, Vol. 4, n. 3, p. 140.

(53) Louisville Daily Journal, August 15, 1855. 
the street. This fact with the exager ted revort that guns and ammunition were hidden in 'winn's houses' excited to a frenzy a mob of Americans already crazed with similar excitement; shooting and bloodshed occurred on both sides at other points. (54)

is Mr. lesster recalled, the row of houses on $\mathrm{W}$ in street between Meventh and Twelfth rere guarded by sore know-Nothings ant "unon any of the tenants venturing to escape they vere immediately shot down." (55) One man in Fatrick hinn's house tried to esmane dressed as a woman, hut he was caught and shot. Inother man concealed hinself in a matress and had his wife carry him out that way. He was torn from the orms of his wife and shot. Still another man, wrapoed in a hlanket and leanirg on the ram of his wife, ws also deliberately shot by the rioters. (56)

"The acts of incendiarism do not compare in atrocity with the dreadful murders. retched inhahjtants meached the street only to meet jeath in another form. A number were taken of $\mathrm{f}$ badlv wounded and others, shot to oieces, returned to the burnine nouses, preferring rather to he burned than to meet the infuriated mob." (57)

Patrick uinn himself, "brother of an Irish cotholic priest was shot and beaten ant thon hurned"....(58)

Mr. Temple bodlev, mentioned hove, recalls as a little hoy being whened at night and seeing the sky red from the burning of the houses in "quinn's Row". In all, twelve houses vere set fire to and burned on the nor th side of Win, east of Fleventh, two adjoining on Eleventh, ant two on the south side of lain. (59) The mob, 400 strong, "having satisfied its appetite for blood,

(54) History of Ohio Fills Counties, p. 316

(55) Louisville ivek Ly Courier, Aupust 11, 1855

(56) Ibid.

(57) Ibid.

(58) Louisville Veekly Courier, August 11,1855

(59) History of Ohio ralls Counties, 0.316 
repaired to Third Street and until midnight made demonstrations against the "Times" and the "Democrat". At one o'clock tris morning a large fire was raging in the upper part of the city". (60) It was reported that Prentice's editorials had greatly aroused the know-liothing followers against the Times newspaper and they were bent on destroying it.

Some of the civic leaders in Louisville performed heroic service in tying to suppress the frenzied mobs. But for the intervention of layor Barbee and Bishop Spaulding, several Catholic churches would certainly have been damaged. The raid, last Wonday night, on the Times newspaper building would have resulted in disaster but for the presence of Mr. George D. Prentice, who it is said, on that occasion made the only public address of his carter. Marshall Kidd and a portion of the police, and the personal efforts of Honorable Milliam F. Thomasson, Captain L. H. Kousceau, Colonel William Preston ( the anti-know-ilothing candidate for Uongress), Joseph burton and others, at different times and places, stopped the bloodshed. (61) Judge Bullock had been instrumental in havinf a number of Germans and Irishmen locked in jail for their own protection. Some know-lothing rioters heard of this and stnged a demonstration in front of Judge bullock's house. The iudge, s small, pompous man came out and fearlessly faced the mob, derouncing them in scathing terms. They soon dispersed. (62) The work of Eishop Uartin L. Spaulding of the Catholic church in nuieting the distarbances and aiding the restoration of order to the city was particularly comendable. Le had prevented a mob from attacking the church at Fifth and Green Streets. One historian has this to say regarding Bishop Spaulding's service:

"For several days after, fears of renewal of the desperate

(60) Louisville Weekly Courier, August 11, 1856

(61) History of Ohio Fills Counties, p. 316

(62) Rolated by Mir. Temple Bodloy. 
conflict and work of destruction, hung like a funeral pall over the city. A card from the Rt. Reverend Martin L. Spaulding and the steady efforts of many good citizens gradually restored a feeling of quiet and security". (63) The card of keverend spaulding read as follows: (\&4)

"Fellow-citizens; In the Louisville Journal of this morning I find the following passage: Te are not now prepared to say that they (assaults commit. ted by foreigners)..... owere instigated b! direct instructions of men with fiendish hearts who control in a great measure the pascions and are able to dictate actions to the Germans and Irich, who made these attacks".

"If, as some have understood it--this mess: $=$ meant to refer to the Catholic ishop and Priests of this cit , I beg respectfully but most distinctly and earnestly to deny the truth of the injurious insinuation conveyed by its language, I have ryself been until the last day or two confined to my room for two weeks by illness and I have the most pasitive information that noe of the Catholic cleroy of this city hatr had any agency in bringing about the recent lamentable outrages which no one deplores more than we do. Our voice has beer uniformly for peace. Me have not even in any way interferred in the last election being overwhelmed by laborious duties in a different sphere altogether.....

"To, all whom the influence of my voice can in any way reach, I beg to say that I entreat them in the name of Jesus Christ, the God of Peace, to abstain from all violence, to remain quietly at home or attending to treir business, to keep away from all excited assemblies and if they think they have been injured, to return good for evil and to pray for those who have wronged them. I appeal to them and to the world whether this $2 a$ not been alway the tenor of my instruotions to them, both public and private, and also that of 1 in tho catholiorclergy.

"I have too high an opinion of my fellow-ctizens of every class to beliave for a monent that the threats which have been made by some will be carried out. I entreat all to pause and reflect, to comnit no violence which they would regret in their cooler moments, to believe no idle rumors, and to cultivate that peace and love which are characteristic of the religion of Christ. "Ne are to remain on earth but a few years; let us not add to the necessary ills of life those more awful ones of civil feud and hloody strife."

$$
\text { M. L. Spaulding. }
$$

The number of penple killed and wounded in the ints of "iloody

Honday" is not definitely know. Estimates of the numier killed rangedfrom

twenty to one hundred. The most common fifure given is $+\cdots, j y-t$ to and that

(63) History of the Ohio Falls Counties, p. 316.

(64) Louisville Evening Bulletin, August 7,1855. 
is probabIy as near $1 \%$ correct as we can get. Bishop Spaulding was quoted in the Catholic Morld that "nearly one hundred Irish and Germans were butchered or burnt and some twenty houses were burnt to the ground.....the city authorities looked calmly on and are now endeavoring to lay the blame on the Catholics." (65) This account is undoubtedly exaggerated in every detail. No other report places the number killed as high as that and certainly the city authorities tried to stave off the excesses of the nobs. The mistake of the city authorities was not that they "looked calmly on" but that they had not made adequate preparation to conduct the election in an orderly manner.

Harper's hagazine carried the following account of "Bloody Honday" in the issue of September, 1855: (66)

"Very serious riots occurred in Louisville on the day of the election, August 6,1855 , between the Irish and the Americans, in which firearms were freely used on both sides, buildings were burned and some twenty persons lost their lives. The canvass in Kentucky has been conducted with great bitterness and animosity."

The Louisville Courier stated that twenty-two people ware killed and many more wounded. "The Irish suffered the most injury." (67) Curiously enough those who were most mistreated, were put in jail. Father Able, a Catholic priest, was rofused admittance to the jail when he called to administer spiritual blescing to those of his congregation who had suffered in the rioting of "Bloody Monday".

Several days later the editor of the Louisvillo Weekly Courier describes the scene of some of the most ho rrinle events of "Bloody flonday". "Visiting yesterday the scenes of these outrages wo were sichoned at the ruin that had been wrought. The poor inhabitants were gathered around the romnants of their property, terrified at every sound lest it might be the signal of

(65) Catholic World, Vol. 57, July 1893, p. 514

(66) Harper's Magazine, September, 1855, VOI. XI, p. 544.

(67) Louisville Weokly Courier, August 18, 1855. 
another attack." (68)

Dr. G. A. Ronald, clearing away the rubbish heap at the place where Patrick Quinn's property was destroyed, found a number of bones which he said were human hones. (69) Coroner $\%$. Lee "thite said the "report that the remains of human bodies had been found among the ruins of Quinn's houses is without foundation. Up to last night, all the burnt bones found in the ruins would not fill the hollow of a man's hand and it is as likely that thoy were the bones of a dog or some other animal as those of a human being." (70)

As a result of the election the know-ivothings were successful in the entire state. In Louisville, Horehead received 3,226 votes to 1890 votes for Clarke. In the entire Seventh Distirct, horehead had a majority of 2,016 over Beverly Clarke. Forehead and his state Know-Nothing ticket had a 4,500 majority. (71)

Humphrey farshall, the Know-Nothing candidate for Congress, defeated Colonel "william Preston by a vote of 3,276 to 1,450 . The city of Louisville gave warshall a majority of 1,004 and Jefferson County gave hin a majority of 299. In the race for state senator the fmerican candidate, Charles Ripley, won in the first six wards, and Colonel I. Haggin won in the other two city wards and in Jefferson County. For the House of Representatives J. G. Lyons, L. A. "hitely, E. S. Worthington, and ". S. Bodley, all know-irothing candidates, were victorious. (72) All over the state the know-Nothings won an overwhelming vote.

Immediately following election day all the contending factions in

(68) Louisville Weekly Courier, August 11, 1855.

(69) Inid., August 18, 1855.

(70) Louisville Evening Bulletin, August 9, 1855.

(71) Johnston, I. Stoddard, hemorial History of Louisville, from its first settlement to the year $18 \overline{96}$, Chicapo and ivew York; American Biographical Publishing Company, p. 131.

(72) Louisville eokly Courier, August 11, 1855. 
Louisville began the task of condeming the barbarity of the opposition and vindicating their own position.

The Louisville Daily Journal accused the foreign element of having made extensive preparations for election day. In this fact the knowNothings saw that every evil deed comnitted by the foreign element was premeditated. "Germans and Irish prepared themselves with scores and hundreds of firearms not to nake or resist actression at the polls but to shoot down Americans from harricaded houses at points remote from the places of voting." (73) According to the Anerican apologists, the situation that arose later in the day at Patrick Quinn's was also part of a well-planned plot to wipe out the American adherents. The know-dothing orean said, "Ve deeply regret in. Quinn's death, vet all the evidence proves that his blood is upon his own hexd." (74) The Democratic papers pointed out that ifr. Quinn had beon a respected citizen of Louisvills for about twenty years and had never been guilty of purposely stirring up trouble. "The riots did origingte with the anti-Ainerican party and were as much preconceived and determined by that party as ever a battle was by a commanding general." (75) Keferring again to the affair at "Quinn's Row" the Daily. Journal says:

"We must bef to concentrate public attention upon the one great important fact.....that, up to the moment when the German shootings from the houses in the upper ward, the Irish shootings in the lower ward began, the streets were as quiet as any street in the city at this moment..... a destructive foreign fire was opened from the houses upon unoffending native citizens...... Any allegation that all this was done without premeditation...... is too absurd to impoee upon any man worthy of notice."

The Louisville Daily Journal did not try to minimize the violence that attended the election, adding "we do not do $t$, that, in some instances, the Americans there were wrong, yet a prominent gentle man of the sixth ward informs us that the first violence was a blow given by an Irishman to an Amer-

(73) Louisville Daily Journal, August 15, 1855.

(74) Daily Democrat, August 9, 1855, quoting the Louisvillo Daily Journal. (75) Louisvillo Daily Journal, August 15, 1855. 
ican for quietly challenging his $r$ ight to vote." In the opinion of the KnowWothing newspapers, even admitting some guilt on the part of the American party, "such things could be no justification for the acts of the cernans and Irish for opening a ceneral fire from their houses at places remote from the polls--their general and simultaneous use of firearms was one of the most dreadful outraces recorded in the history of the cities of the United States. Foreigners wore influenced by demagogues into thinking they had an innate right to vote." (76)

"The native-horn American citizens thought and felt that if any portion of the penple legally entitled to vote should have to stand back and lose their suffrages for want of time, the foreign-horn citizens should stand rack rather than themselves..... Unquestionably they pressed forward early and vigorously to the polls, in order to be the first, if possible, and in this they were right." (77)

A Cincinnati newspaper, discussing the events of "Bloody Konday", said that foreigners had been gathering powder in the seventh ward preparatory to a new series of trouble with the know-ivothings. Also, bolonel Preston was accused b; this newspaper of being the leader of the anti-American forces against the know-Nothings. The Louisville Weekly Courier denies this, saving, "the foreigners had not even made preparation to defend thens lves in case of an attack'. (78) On the polling day Colonel Preston saw how the election wrs coine and advised his friends to leave the polls--"rather lose by defalt than provoke trouhle". (79)

Catholic sympathizers were not slow in pointing out that the Know-ibothing mobsters had directly attacked Catholic church property. Eishop. Spalding formally demanded protection of layor barbee and the bishop also defended the "sturdy Teutons who armed themselver against their assassins."

(76) Louisville Daily Journal, August 15, 1855.

(77) Ibid., August 16, 1855.

(78) Louisville Neekly Courier, August 18, 1855.

(79) Ibià., August 11, 1855. 
In a letter to Arch-Bishop Kerrick, $\mathrm{p}$. Bishop Spaulding said, "The atrocities of 'Bloody Monday' have never been equalled in this country. We have just passed through a region of terror, surpassed only by the Philadelnhia riots. Nearly a hundred poor Irishmen and Germans have been butchered and burned and some twenty houses have heen fired and hurned to the pround. (0, According to the Gatholies the city officials were sorry for their part in the know-Nothing party. Prentice, Nyor Barbee, Humphrey Narshall, and Judge Caleb Logan expressed in Vr. vebb's (Catholic 1ayman) presence, "their sincere reprets th"t they had ever had any connection with the movement". (81)

The Louisville Daily Journal was roundly accused as being principally responsible for the "Bloody londay" riots. George D. Prentice, for his vitriolic utterances on his editorial pages, was held by many to be personally resnonsible for the outrages. The Daily tournal editorials ws, in the eves of Georre D. Prentice, mole proof of the guilt of the anti-now-nothing forces. (82) Also many out-of-state Democratic organizations aver thet the real trouble wa started by the anti-Know-Nothings. (83) Teferring to the actual casunlties, the Iouisille Daily Journal makes the extreme statement that "in the upper part of the city at least twenty men an one hor were shot in the peacerul streets and were veltering in their bloot hefore a solitary weon was raised aguinst the nerpetrators". To the comment rade by the Daily Demormat hevilima the loss of hlood by foreimers the Daily Journal observes that the Demoerat does not hother to "pxplain why he hus not a ford to say about native-- about the blood of between twenty und thirt" ntives that staned our streets before a

(80) Webb, Kenjamin J., Centenary of crolicity in Kentucky, Louisville kohers, 1814, p. 484

(81) Catholic rorld, Vol. 57, July 1893, p. 515

(82) Louisville Daily Journal, iugust 16,1855

(83) Ibid., august $17, \overline{1855}$ 
drop of Irish or German blood began to flow." (84)

An intellipent Catholin Layman of Louisville, Lenjamin "ebb, with

wom reor D. Prentice had many editorial clashes, said this of Frentice:

"....fornerly a votary of the getlest of the nuses, he has turned his pipe

to znother lay: Arma virum que cano--war is now his theme; and the onject of

is hichest ambition is to breal a latce with the Papal uragonlu. (85)

The Louisville Times in reply to Prentice's appeal for know- ooth-

ing suscoriptions said, "Does not he consiler hinself sufficiently paid for

haring scores of Germans and Irish nurdered." (86)

The Louisville "eelly Courior lamed the dounal for the worst excesses of "sloody fonday" because of "incendiary articles". "Ivery action of the know-othings tended to produce the damnable oitrage. They prevented the allocation of additional voting places, determined that a full vote should not be polled, and had Know-Nothings appointed almost exclusivelyas election officials." (87)

Ben web further states that George D. Prentice's acticn did not reflect his personai hatred or bigotr. but that irentice was "governed more by policy than by principle". It was through selfish interest and the persuasion of friends that he was induced to foin hands with political malcontents. iie had sold hinself to his part; for defensoiva as well as affressive action.... "From this time bagan the decadence of his fame." (88)

Denjamin rebb writing in his book, Centenary of Catholieity, says, "a report in the Louisville Daily lournal, August 6 , that the killirg, mainirg and burning of the day before had been the direct result of assaults made upon peaceable citizens by the foreign-iorn elements of the population, and intimating, too, that these assaults were instigated by the Catholic clergy of the

(84) Ibid., August 15, 1855.

(85) Catholic Torld, Vol. 57, 1873, p. 517 .

(86) Louisville Times, January 23, 1850.

(87) Louisville Teekly Courier, August 11, 1855.

(88) Tebb, Catholicity, pp. $483,-485$. 
city." $(89)$

"Geore D. Prentice was nost responsible for "bloody wonday".

There is scarcely a doubt that through selfish irterests and the persuasion of part fricnds that he was induced to join hands with the nalcontent politicians of the day. He excused the mob as fiar as he could and he sought, as bishop Spaulding truly says, to cast upon the victims of its lury all responsibility for the events." (90)

The louisville Teelly wourier had been rather vigorous in its attack on the Iouisville Daily Journal althourh it pretended to be a neutral, 3on-partisan newspaper. In December, 1855, when the controversy over "Eioody conday" was still being hotly discussed that newspaper advocated a sudded cessation of all discussion and rantine about the unfortunate August election. Probably the effect of the riots on Louisville's prosperity was real. At any rate the Louisville "eekly Courier maintained that a fair and peaceful election would have easily assured Preston a majority of "at least $600 "$. (92)

The fact that even the police force on election day were know-Nothing sympathizers is cited by the "reely Courier in support of their contention that the foreigners in Louisville vere not giver a fair chance to vote. (93) rhe "election tables were published only as a netter of form. The election vas really no election at all. A nice sense of honor would prompt a gentleman to decline receiving certif'icates of election won under such circumstances." (94)

The courier did not blame all the know-iothings for ronday's trouble because they know many of the know-Wothings were the most prominent men in the city. Iany of the ruffians were imported. (95) the louisvilie

(89) web: Catholicity, p. 485.

(90) Ibid.

(91) Louisville "leekly Courier, December 15, 1855.

(92) Ibid., August 11, 1855 .

(93) Ibid., August 18, 1855.

(94) Ibid., August 11, 1855

(95) Louisville Neekly Courier, August 18, 1855. 
"eekly Courier was prevented from reverlinp facts of riots honday because of threats of Know-Hothings against property and enployees of the Louisville "Negkly Courier. According to the louisville "yeliy Courier no "greater curse has certainly ever fallen upon our fair city than thus to be placed under the yoke of know-Nothingism. As a national party know-lothincism is already defunct. It is a consolatary reflection to know that these unparalleled outrages in Louistille are the last efforts of a dying faction--tre spasms of its lact agenies." ( $\Delta E)$

The out-of-town press yas very forceful in its condemnation of the laxity of city officials in regulatine the election on londay, August the sixth. The liew York Courier and Enquirer asked, "where was the military? It had been distinctly forseen that tiere was danger of public disturbance on election day." (97) There was "no precuution taken by municipal authorities amainst the apprehended evil. io riot has occurred for years that occssioned the destruction of such an amount of life." It seemed incredible to New rork papers that the city authorities had been incapable of doing something about the riat. Responsibility is resting on Louisville officials who failed "most discreditably in their official duty." (98) Regardless of which side should ultimately he blamed for the riats of "Bloody Monday" "the verdict concerning the municipal authorities of Louisville is already made up." (9o)

The conclusions reached by the New York Tribune probably gives a more accurate conclusion than can be found in any newspaper--certainly more reliable than any Louisville newspaper account. Conclusions contained in that paper follow:

"1. The city admiristration was strongly know-llothing.

(96) Ibid., August $11,1855$.

(97) Ibid., August 18, 1855 .

(98) Ibid.,

(99) Louisville Daily Democrat, August 14, 1855. 
2. More polling places were needed.

3. The anti-know-liothing appeal for more voting places was ignored.

4. Polls were surrounded by nembers of the KnowNothing party, the "midnight order".

5. The adopted citizens commenced the riotine but were justified.

6 . The Catholic Cathedral was saved by the mayor. The attack was aede becruse of ramor that arms were hidden there." (100)

Mayor Barbee made this statenent in regard to the efforts made to preserve peace on "Bloody inonday", "Ny efforts, aided by the police, were wholly unavailing". (101) the Common Council, at the rayor's suggestion, passed a resolution recommending a thorough investigation of the rioting. Not only was there an investigation to deal with the responsibility for the riot but also an investipation to report on the destitution in several sections of the city. Any number of people, pretending destitution, went about the city begging alms. "Colonel Duerson of the Alms itouse is securing a list of sufferers from the riots." (102) Yet, no one denied that in many cases there was real destitution and in order to meet this emergency the Common Couricil passed the following resolution;

"Wereas, a portion for our foreign-born population, by deeds of violence and bloodshed, provoking our native-born citizens to measures of retaliation, his brought upon many families of both classes destitution strongly appealing to public symathy; Therefore, Resolved by the General Council of the City of Louisville that $\mathbb{E}$ is $\mathbb{E}$ onor, the faror be and is hereby requested to inquire into the conditions and necessities of said families and report to the Ceneral Council as soon as he conveniently can, what sum is requisite to provide them with all proper necessaries for the time being." (103)

In pursuance of the recomendation to investigate responsibility

for the rioting a committee, headed by a Mr. Gillis submitted a report which mas a vindication of the Know-..othing party. According to this report all the (100) Louisville "leekly Courier, Aupust 25, 1855. (101) fbid. (102) Louisville Daily Journal, August 25, 1855. (103) Joint Resolutions, General Council of the City of Louisville, August 11, 1855. 
polling places on election day were quiet "as seen by a portion of your committee" and the "foreign population commenced the difficulties in every instance. All the disturbances originated at a distance from the polls." (IO4)

Gillis ' report follows:

"The property known as 'uinn's Row' was a complete armory. Powder and arms had been stored there for three weeks before election. quinn asserted that said guns would be used against Americans." (I05)

To substantiate this statement Gillis referred to David L. Beatty, member of the Council, and to George . Griffey, street inspector for the western district, both of whom corroborated Gillis' statement.

"By these priest-ridden foreign hirelings and from the walls of these desecrated habitations ...Americans were shot down without nrovocation. On Shelby street houses occupied by foreigners were mostly sunplied with guns. - Your committee concludes that the foreign-horn population, aided by would-be Americans planned and set in motion the machinery from which the disturbances originated." (IO6)

The Gillis' committee asked that this report be adopted by the Common Council and this was done by a unanimous vote. (IOT) By mistake the report made by Gillis' comittee was placed before the Borrd of Alderman and they immediately tabled it. The Daily Democrat commends the alderman on their'sensible gesture".(I08) "ith reference to the report the Daily Democrat pointed out the inconsistency in the admission by the Louisville Daily Journal that disturbances had occurred at some of the polls and the Gillis report that all had been quiet at the polls.(I09)

With reference to the prevalent destitution in Louisville following "Bloody Nonday" the following resolution was passed by the General council:(IIO)

"It is resolved by the General Council of the City of Louis-

(I04) Louisville feekly courier, August 25 , I 255

(IO5) Thid.

(T06) Ibid.

(I07) Ibid.

(I08) Louisvilie Daily Democrat, tugust 23, I855

(I09) Ibid.

(IIO) Joint Resolution, General Council of the City of Louisville, August I8, I855. 
ville that the sum of five hundred $(\$ 500.00)$ dollars be and the same is hereby appropriated for the relief of destitute percons who have suffered by the riots in the first and eighth wards, the same to he placed in the hands of John varbee, ifayor, for disticibution and the Auditor is hereby directed to draw a warrant on the Treasury in favor of the layor and charge to incidental expenses and the Hevor shall report how the sum is disbursed." (111)

The General Council, meeting in session August 25, 1855, passed

two interesting resolutions, one referring to the fire that had destroved

"Quinn's property and the other dealing with the salaries of the special police-

men. Excerpts from these resolutions follow. (112)

1. "Resolved by the General Council of the City of

Louisville that the following sums be allowed the

following persons for services rendered at the fire at

Ifain and Eleventh Streets:

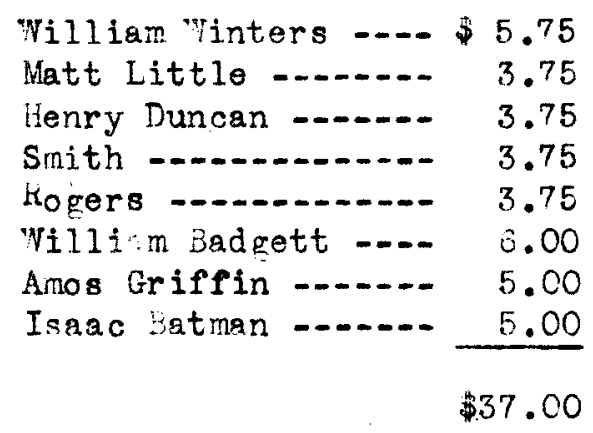

Approved August 25, 1855

2. "Resolved that the sum of 109 dollars be and the saine is hereby appropriated in the hands of his

Honor the Nayor to be by him paid to the persons aamed

in his communication and charge the same to incidental expenses."

Undoubtedly the excesses of "Bloody Monday" had a retarding effect on Louisville. At the time of the unfortunate election Louisville was growing rapidly and was especially proud of the industrial progress of the city. Mlthough many considered the national strength of the know-Nothing party to be in decline, the election in Louisville caused foreigners to look with

(1II) Ibid.

(112) Ibid., August 23, 1855. 
disfavor on Kentucky as a place to make a home. "The only effect of the temporary triumph was to give Kentucky a bad name among the immigrants from which it never recovered as shown by the fact that in her population of two millions she has but sixty thousand persons of foreign birth within her borders." (113) The last censis showed a population of $1,858,635$ of which only 59,356 were of foreign birth. (114)

bishop Spauldine, making a missionary trip throuph his dionese following "Bloody honday" said, "the recent know-Nothing excitement and crusade against the Catholics have rendered the latter more zealous in the faith.... persecution benefits its victins." (115)

Bishop Spaulding pave a very striking story of the effect of the August election on Louisville but it is probably overdrawn. He said, "In Louisville there was no market for realestate; no new enterprises were stsrted; prass orew in the streets and homs sunned tremselves in the filth of the gutters; and this stagnation did not pass avay until the awful storm of Civil war had passed over it and purified the air." (116) "Thenfor days together one nizht walk the streets without meeting a single Irish or German citizen. Hundred of them, as coon as ther could possibly arrange their affairs, moved awa from the city altogether." (117)

of course for sometire following the August election any slowing up of Louisville's development was most certainly blamed on that election. The anti-know-inting journals accounted for the small number of foreigners in that way. However, it is cross over simplification to attribute the general bus iness condition of Louisville to "Bloody londay" troubles. For example,

(113) Memorial istery of Louisville, p. 133

(114) Ibid., p. 100.

(115) Louisville Neekly Courier, Novamber $31,1855$.

(116) Catholic World, July 1893, p. 520.

(117) webb, Catholicy, p. 485 . 
one anti-know-Notring organ attributes the fact that Louigville municipal bonds sold twenty-eight cents less in 1857 than 1855 to the election of August 6 , 1855. This obviously untrue. Mhat is true is that the constant, irritating gitation carried on by the Iouisville nerspapers before and after that alection undoubtedly had an unsettling effect on Louisville industrial life. Louisville business nen were not $s$ low to appreciate this fact and a contittee was named from anong the business nen of Louisville to forward the following resolution to the editors of the city: (118)

\footnotetext{
"Resolved: That the public prints of our city be raxasted to discontinue the discussion of the prosperity of this city, so far as the said prints may have cornected the sime with issides of political parties."
}

Samuel Casseday, Cheirman Thomas F. Whighes, Secretary

A setition presented by S. S. Nicholas, R. M. "ard, James Rudd, and others raquested that the city of Louisville bear tre expenses arising as a result of the damage to private property in the rints of "Bloody londay". "Legal liability of the city was conclusively nepative by the decision of tho Court of Apperls of Kentucky. The city has no power to appropriate noney from the regular funds and no other funds are available." (119) It was perhaps unwise to pay the money even if the city could have done so. "If the precedent be established trat they can do whaterer their evil passions prompt them to do, and then receive compensations from all losses, they will be freed from a very necessury and wholesome restraint." (120)

Al Act of the Coneral fscembly, passed February 29, 1860, authorizing the levy of $a$ tax sufficient to pry, with interest from the date of the

(118) Daily Louisville Times, April 24, 1856

(119) Louisville Evening Bulletin, August 27, 1855.

(120) Ibid. 
riot, such amounts as shall be ascertained and adjudged to be due by the Crancellor of the Louisville Chancery Court. (121)

Thus ended one of the most disgraceful episodes ever to ocour in an American city. "Bloody "fonday" had claimed the attention of the whole country and the effect had been to cause people to regard with horror the ugly portent of racial varfare and religious intolerance. Sowever, the know-Nothing organization was fast losing its appeal to the country and the slavery issue was further dividing the party into two canos. A know-Nothing neeting in Louisville, September 1, 1855, frankly admitted that some of the rational platform features ware clearly objectionable. (122) Many northern states had repudiated the national platform and dissclved their Know-iothing Councils. They were fast falling into line with the powerful Republican Party movement. Kentucky know-Nothing nembers, although they were fast deserting the "sinkine ship", wore not as exsily won to the Republican Party. Particularly in Louisville the know-liothing party continued strong for at least two years and then combined with the Constitutional Union party in 1860.

(121) Johnson, ffemorial History of Louisville, p. $100 \mathrm{~V}$ Vol. I and Journal of touse of Representatives, Dec. 5, 1859, Karch 5, 1860, Kentucky Yoemans Office, 1859 ,

(120) Louisville Weekly Courier, Septemier, 1855.

(123) Connelly : Coulter, page 852 . 
CH:PTER V

THE KNON-NOTHINGS AN TEF ELEOTTON OF 1856 


\section{CHAPTER V}

The Know-Nothings, and the Election of 1856

The Act of the General Assemily in righting the wrongs that,

had been perpetrated on "Bloody inday" by no neans ended the controversy hetween the know-Nothings and the Democratic party. Although the national know-Hothing organization began to decline in 1856 due to its inability to dodge the slavery question, the political controversy in Louisville ran strong for several years.

The organization of the know-Nothine party in Kentucky was of "Iittle vitality". (1) The American party in Kentucky was, like the organization in nost of the country, in ergve danger of falling apart. An adjunct to the Know-Nothing party, the Temperance Farty, had fallen to pisces. the American party in harch 1856 issued a circilar to its kentucky constituents in an effort to "arouse once more that fervent zeal and patrintic spirit trat animated you on the 6th of August last when you won a most brilliant victory."(2)

$$
\text { The effort to "arouse once more" the zeal of "Hloody conday" may }
$$
be taken $a s$ an indication that the know-Nothing party was losing its popularity; that is certainly the fact, at any rate.

Prior to this significant circularization the Ynow-ivothing National Convention had net in Fhiladelphia, Februgry, 1856, and had further disintegrated as a real national party. The platform for the convention had already neen drawn up by the National Council and, sienificantly enough, this platform had repealed the extrenely pro-sourthern section twelve regardine slavery and, in its place, had adopted a new one which avoided ar explicit expression of the

(1) Connelly * Coulter, p. 848 .

(2) Ibid. 
maty's views on slavery but wich wes generally furahle to the South. The section evated the issue by declaring laws constitutionally enacted must be enforced until regularly repealed and adjudged rull and void. (3) Defeated on a motion to deny the binding authority of this platform many northern delegtes withdrew. The remaining deleg tes nominated killard Fillmore and indrew Jackson Donelson for president and vice-presilent, resnectively. is the Daily Iouisville Times aptly put the situation, "the mortsin had labored and hroupht forth a mouse".

One significant provision of the party platform refers to the loss of secrecy:

"Pach state council shall have authority to imend their several constitutions so as to gholish the several derrees and institite a pledge of horor inste of the other obligations, , t free and open discussion of all the political principles embraced in our nlitform."

The attempt of the Know-Nothing convention to apnease the North hy eliminating the controversi 1 section 12 and at the same time retain, hy insinuntion, the allegiance of the South, could not he none. Likenise, by trying to retain a firm hold in sections that were strongly Catholic while they were also trving to reep the anti-Catholics from breakind a wy from the party was also attemnting the vell-nigh imoossible. The platform tried to anpesse Catholins and the anti-catholics, slavery symnthizers, and slavery onponents. This could not be done.

In April, 1855, the regular election for Common Councilmen and Aldermen took place. The Democrats vere not very hopeful of successfully opposing the Know-Nothings as a regular party organization. Consequently, in an effort to unite various factions in the common couse of defeating the know-

(3) Cole, A.C., inig Party in South. p. 322

(4) Daily Louisville Times, February 25, 1956 
Nothing ticket they asked the question, "Cannot an Independent ticket be put in nomination ggainst them (know-vothings)? Those having at heart the success of the Public Schools--the efficient organization of our Fire Companies--and those opposed to fools and fanatics, might present and elect a good ticket." (5) This may have been one hope of the Democratic party but the prevailing thought of the anti-know-Noting forces was one of utter hopelessness. The changes, according to the Democratic or an, that had taken place in Louisville were tremendous and the Daily Louisville Times wrote that "we have lost one-third of our trade and instead of increasing our population, thousands of industrious citizens have been driven out to seok homes elsewhere. From all indications we can soe hut little hope for a change." (6) This attitude seemed to be rather general in the Democratic party. They considered that they had still less opportunity of thwarting the know-Notrings than in August, 1855, because the "outrages then committed upon foreign-born Democrats and still greater crime of the 6 th of the follwoing August will prevent a large maiority of them from again endeavoring to exercise the richt of suffrage." (7)

The Know-Notring party presented nominees in 911 wards and with few exceptions these noninees were unopposed. There were "but few announcements of opposition to the know-Nothing ticket. In the seventh ward air. $\mathrm{a}$. I. Durrett, Old Line whig, has announced for the Common Council and in the sixth ward Joe Retcalfe was called on by many voters to become a candiate for the Common Council." ( 8 )

The attitude of the Democratic prose may he ascertained by the followine statement: "Ye suppose a woree nomination was never made than this ticket precented by the know-iothins and we know of no hope for the city if

(5) Ibid., March 28, 1856

(6) Daily Louisville Times, March 20, 1856.

(7) Ibid.

(8) Ibid., March 18, 1856 
it should be elected, short of the interposition of Divine Frovidence." (9)

The election, which took place on Saturlay, April 5, 1856, resulted

in "favor of the know-ivothines as matter of course. Adopted citizens would not

Eo to the polls as they rad not made their wills and did not desire to die." (10)

"Of the 3000 Democratic votes in Iouisville only 600 of them were allowed to

vote." (11) For several days the Louisville Daily Journal called on the know-

Wothings to rally in full strength at the polls; the interest o: the Know-

was

Nothings/aroused by saving that the Democrats had secretly armed and their

real strength was consecuently unknown. "On the evening before election day a

numer of foreigners stopped work, took their wives and children and went to

the country. 'Americans' went to Fortland where the Democrats vere leading

and offered to bet that no another Democratic vote would he taken." (12)

Before the election of Auguet 4, 1856, for the offices of Chancellor

and Comonwealth's Attorney, an effort was nade to mat the Louisville election

proceedure on a dignified respectable basis. On May 27,1856 an ordinance was

introduced by Alderman Farris before the board contgining the followine sections:

Section 1: "At all state and numicipal elections beld in the city of Louisville, it shall be the duty of the

chief of police to station at each voting place a sufficient police force to keop the polls clear, to suppress all riots and dicturbances.

Section 2: After a person has voted te must retire sixty feet. Failure to do this will result in $a 50$. Fine.

Section 3: It is the duty of the city to prevent obstruction of the voting privilege.

Section 4: Citizens may be enrolled by the Chief of Folice to supplement the regular police. They shall

he paid as tie regular police from special appropriation made after election.

(9) Inid.

(10) Daily Louisville Times, April 11, 1856 quoted from Bardstown Gazette.

(11) Daily Louisville Times, April 12, 1856.

(12) Ibid.

(13) Ibid., Lay 29, 1856 
Section 5: Dismissil for failure to perform above duties. This aplies to a11, from the Chief of Folice on down.

Section 6: The rayor shall enforce the ordinance and have the same printed in daily city papers one month preceding the next August elections."

The board of Alcernen unaninously passed this ordinance wich would have made 3 very needed improvenent in the election procedure. The Comon Council, bowver, rejected the Ordinance on the oround that the provisions were warlike in character. The Common Council referred to Louisville as the "halcyon of peace". Mitr reference to this phrase the Daily Louisville Iimes said, "The halcron, our readers will remenber, was a f'abulous bird in anoient muth, and tis one is equally so." (14)

The election for county offices August 4, 1856, was rither colorless. The Democrats did not nominate any candidates for office, their strategy being to let the Know-Wothings ruin themelves in office and then the Derocrets could rin without much trouble.

The Know-Vothing candidates for the najor nfices were Caleb w. Logan for chamcellor, "illiam F. Bullock for Circuit Judge, and E. Craig, an "intense Amerioan", for Comonwealth's attorney. Hr. Genry Firtle, wo had been Chancellor for several terins had been urged to becone the know-liothing candidate for the office of cancellor. The know-lot ing national presidnet, t. F. Eartlett, a Ventucrian, came to Loxisville and tried to get firtle to run on the Rnow* lothing ticket but Pirtle eventially ran as an Independent. Alt'ole' no vinlence was expected 'gor Earbse issued the followprociamation: (15)

(14) Daily Louisville Times, June 13, 1856

(15) Daily Democrat, August $4,1356$. 
Wayor's Office

July 28,1856

Louisville, Kentucky

To the Sitizens of Louisville:

"As fears exist in the ninds of many good citizens that the approaching elections in August and lovember may be the occasion of riotous and disorderly conduct in the city, growing out cf an excited state of party feeling, T have thougt it proper... to is sue special instructions to the crief of Folice to prevent a bresch of the peace.

I now appeal to all good citizens to aid the officers in the discharge of their duties..... and it is enjoined upon all parents an elardiars to keep tieir cildren from the polls or claces of voting...

The peace of the city nust be preservod law and order mact prevail. To secure tris, provision las been made, and force will be resorted to, if hilder means will not suffice."

$$
\text { John Larbee, ayor }
$$

The mayor also reauested "owners of coffee louses to close their holser and not vend spiritous liouors on election day, "and also to keep away from the nolls. Last rear buckets of whiskey were in the hands of Americans at the polls to quanch sam's thirst." (16)

The election actually ws conducts mith ver, few disturbances.

The Democrat savs "tho Know-rothines belc a very solem election yosterday. "Te heard of' no disturbances at the polls. The Je coratic party rad no nominees and there were only trree or four independent candiates. (17) A numer of our foreign-born citizens lett the city in the norning, apprelensive of mon violence, in spite of all assurance. Many native-born voters refuced to vote." (18)

The Denocrate, weeting in convention in Gincinnti, the first week in June, moninted bucharan for Fresident. The Derocrats followed two

(16) Daily Democrat, I Lesday, August 5, 1856

(17) Louisville Daily Couries rugust 4, 1856.

(18) Daily Democrat, August 5, 2856. 
main arguments in the campaign. First, the Democratic party claimed to be the union party. This was probably true at this time because certainly the Know-Nothing party wa divided nationally and the kepublican party, which had full slate of candidates in hentwy in the election, never claimed to be a mion party. The people of Kentucky, probarly nre politically uncertain trian at any time since the iays of Jackson and Clay, only knew t at they were still for the preservation of the Union. The Demerats tried to win know-vothing support by showing that "what was once the old conservative "hig party, ras passed from hands of noderate, conservative ren, and is now being hurried forward in a nid career of folly by the crude and crazed theories of bigots, zealots and denagogues." (19) In an editorial of February 21, 1850, ths Saily Ioulswille Times endeavored to show that the northern Democrats and the Southern Democrats had always acted together on vital issues. "rhile this was becomino less true since the passage of the Kansas-vobrogla Bill, the dissension in the American party, closely following the trend that spelled doom to the Wuif party, could scarcely give that party the right to the name "national party." (20)

The second arginent advanced by the Dexocrats, never successfully met by the know-Nothin:s, we that a vote for Fillmore was in reality a vote for Fremont, the "epublican candighte. There was danger that a division of the vote in the South would make the election of fremont a real possibility. In $f^{\prime}$ ce of this liarper nany know-ivothings and old line Whies deserted to buchanan's cause. The Daily Denocrat said, "Friends of the South ars foopardizing bie position of the South boting for sillmore". (21)

The following editorial seens to be nsar the truth: "The Black

(19) Daily Louisville Times, February 2, 1856.

(20) Cole, A. C. Thig Farty in the South, pp. 322, 323.

(21) Daily Louistille Times, Tune 11,1858 . 
Republicans may cry out against it--the know-Nothings may depreciate it--but t. e action of the Democratic Convention in Gincinnati has insured the perpetuity of the Union." (22)

Several other facts gave the Democrats prestige: one, bucharian Was a Jacksonian Demoerat; Ereckenridge, Democratic candidate for vice-president was a native of Kentucky; then the etrocities of "bloody onday" had damaged the know-iothing cause in kentucky. (23)

The certainty tiat lad prevailed in Louisville during the spring and August elections of $185 e$ vanis ed as tre presidential race arew near. Unce again the Democruts, feeling that in tis election the Know-Nothines were going to be defeated, and the Know-Nothines, rather desperate, prepared for olection day in much the same nanner trat thay had in the summer of 1855 . Ill-feeling in Louisville was a continued ting. The Daily Democrat reports two cases of Germans in Police Court wo vere arrested for being in a bad neighborhood Iuesday, Octoter 21, 1856, and for being Gernans. "They had no business for being guilty of eitier offense......their dialect convicted them of the crine of Gernan nativity." (24) The layor/Louisville iscued the following proclamation on

Novemben 3, 1856:

"In order to prevent riotous and disorderly conduct in the city at the approaching presidential election, I nave thought it proper, in the discharge of ny duties as Layor, to issue special instructions to tro Chief of folice whereby pence and good order may be preserved in the city; and I do now appeal to 211 good citizens to aid tle officers in the discharge of their duties...... It is likewise enjoin-upon all parents and gusidians to keep treir children away from the places of voting.... The peace of the city must be preserved. Law and oreer must prevail. To secure this, provision has been made and force will be resorted to if milder means will not suffice." (25)

(22) Daily Democrat, October 23, 1856.

(23) Mississippi Valley istorical Review, Vol. IV, No. 1, p. 54.

(24) Louisville Daily Democrat, October 23, 1856

(25) Louisville Evening Bullet in, November 3, 1856. 
The leading men of the city, clergymen and laymen alike, urged

a peaceful election. Bjshop spaulding, at the request of the vayor, is sued a request for peace to his communicants.

"In the naine of Jesus Christ, the Prince of Fegce we invoke peace to still the ankry waves of human passion.....

"Wile it is cleariy not our province to interfere witi trie political discussions of the day, it is surely competent for us, under present circumstances, earnestly to ex ort all our fellowcitizens to claim nothing wich the laws do not secure to tem, to exercise even their undoubted eivil rights with due forbearance and noderation, scrupulously respecting the feelings and rights of ot ers...." (26)

A number of leading citizens offered t eir services as volunteer policemen. They were trying to avoid a repetition of the incidents of "Bloody Ionday" by having an adeouate police force to preserve law and order. There were also assurances from city officials and leading citizens to foreigners urging them to remain in the city for the election. Naturally, most assurances of this nature come from Democrats. A vote of six thousand ras expected. 'the Daily Democrat noted "that the nayor nas s own a laudable anxiety on this subject, and tat there is prospect of concern to naintain law and order that will be efrectual". (27)

Louicville business nen were also concerned that the election cive public assurance of the stability of lw and order in Louisville. If a small vote should be polled business nen felt that the idea would be hela that intimidation and violence sad kept many away from the polls. (28)

Altrough the know-Nothings won in the election it passed off quietly. There were a few incidents of intinidations, (29) but on the whole the Democrats were satisfied that the election, under careful official supervision, had been fair. In fact the Democrats claimed a roral victory since for

(26) Louisville Evening Dulletin, November 3, 1856.

(27) The Daily Democrat.

(28) Louisville Courier, November 3, 1856.

(29) Ibid., November 5, 1866. 
"gll the efficient and systematic efforts they(Know-Nothings) have actually lost in the city as compared with forehead's vote." (30)

Fillmore polled 3,328 votes and Juchanan, 2,016, giving sillmore a majority of 1,812. Considering that only 6,000 had been expected to vote the election was a success and apparently tino Nemocrats and the foreigners had been allowed to vote.

The Daily Denocrat said, "We congratulate Louisville that she has presented herself with a much better face than it was aprehended she would, No funerals followed on the election this oity. Lhe result has raised the character of Louisville in the public's estimation." (31)

The total national vote for the candidates was as follows:

Buchanan received 1,838,169: Fremont, 1,341,264; and Fillmore, 874,534. Fillmore had forty-four (44\%) per cent of the Southern vote and thirteen (13\%) per cent of the northern vote. Euchanan carried Kentucky b; a majority of 6,118 over Fillmore, the first time that Kentucky rad gone Democratic in a presidential election since $1828,(32)$

Some historians take the election of 1856 as the point where the know-i thing party in Kentucky began its definite decline. "Fror now on Kentucky was a Democratic state, with virying degrees of insistence on the principles of national democracy." (32) The know-Nothings blamed their defeat on the elevation of the slavery question. (33)

(30) Ibid.

(31) Louisville Daily Democrat, November 10, 1856

(32) Connelly is Collter, page 848.

(33) Ibid., p. 849. 
CF PTFR VI

THE PRSTSTHCE OF KMON-OTHINGS IN LOUTSULTE 


\section{CHAPTER VI}

The Persistence of the know-wothing Farty in Louisville

We have noted that in the election of 1856 the state of Kentucky

as a whole cast its vote for Buchanan while the city of Louisville cast its vote for Fillore. As long as the know-ilothing party retained its familiar name, they were successful in Louisville. In the nation various factors were spelling doom for the know-iothings; the rise of the kepublican party, the inefficient leadership in the party, the barrenness of Know-Nothing legislativeness, the prominence of the slavery issue, and the need for more labor in a rapidiy expanding country.

The Know-Nothing party in Kentucky had approved the southern platform of the party in 1855. Hitl the breakup of the party in other parts of the United States for the ahove named reasons, the Kentucky Know-ivot ings, zealous for the Union, found that the preservation of the Union seened less likely under Know-Nothing standards than under Democratic. sence, inany "Oldline "Wigs who had voted with the know-Noting party in 1855 now joined forces withi the Democrats.

In Louisville for at least three years following the havoc of "Bloody Monday", August 6, 1855, the Know-Nothing party continued to control the local political situation. Even with the rest of tre state in the Demcrats" column, which it was from "Bloody Wonday"on, the wouisville Know-Notrings mere strong. One must not suppose that this was because the people of Louisville were more interested in the preservation of the Union than other people in Kentucky, for this is not true. As noted above, Louisville was one of the Southern centers of know-Nothingism. Frobably the persistence of know-Nothingism in Louisville was simply the normal political development. Because of the 
more intense nativist feeling in Louisville than in any other parts of the state,ard because of the difference in social and economic problems one might rifhtly suppose that Know-Nothingism would last longer in Louisvillo than in any other part of Kentucky. Strength is given to this view by the knowledge that know-lotingism persisted longest in those centers where nativist feeling was keenest. New or leans might be cited as an example of this.

Two very important events occurred in Louisville in 1857 that deserve comment: first, the meeting of the national know-Nothing Convention in Louisville in June, 1857; and second, the August elections of that year. Frior to the meeting of the national convention, Louisville had elected a new nayor, April 4, 1857, In this election very little violence occurred because the Democratic party refused to nominate candidates, well knowing that the Know-Nothings were too powerful to be defeated. According to the Democrutic organ "the Denocracy preferred that the election go by default rather than do aught to disturb the peacs and harmony of our people. Happily.... the election day passed quietly." (1) Organs of both parties agreed that the total vote was very small; the democrats contended that since only about onefifth of the eligible vote was cast the election wa unfair,(2) and the KnowNothines, while admitting that only one-fourth of the eligible vote was cast, attributed the singll vote to the efficiency of the know-Nothings and the inefficient organization of the Denocrats. (3) The Louisville Daily Journal regarded the election as vindication of the know-Nothings for the "Bloody fondry" riots. "he election was according to the know-ivothing organ, "signal evidence of the entire confidence of our citizens of the candidates selected by the American party". (4)

(1) Louisville Daily Lemocrat, April 5, 1857 .

(2) Ibid.

(3) Louisville Daily Journal, April 7, 1857

(4) Ibid., Aprī 6, 1857 . 
"The whole American ticket was elected hy a five-sixth (5/6)

majority of all the votes onst." (5) In the race for mayor nilliam S. Pilcher, the Know-Nothing candidate was opposed hy two indenendent candidates, Captain John M. Vartin and a man numed Oshorne. Pilcher rot 1,110 votes, Nartin ?24, and Oshorne 15 .

In this election there is apain evidence that the Democrats ere poorly ormized for local elections. This dislike for nominations for local elections as somehon denving certain imerican liberties is voiced in a Democratic editorial in Warch, 1857, which criticises the know-Nothing method of "selecting nominees in a very small party meeting" and thus, in some way, violating American liberties. The Know-Nothings mantained that the "imerican Party is not controlled by nerty leaders. It is a prirty of the people..... every American....has an opportunity to denosit his ballot and express his preference." (6)

On June 2,1857 , the national convention of the know-Nothing party met in Iouisville. ccording to the Jemocratic press the convention was very unimpressive. Neeting in a hall Nith a capacity of 1200 "the hnow-liothing convention consisted of fifty-f'ive memers, representing 'sam' from thirteen states". (7)

In this national convention the naty secrecy finally abolished. The fourteonth resolution of the convention out the Know-Nothine sarty on record as advocating "free and open discussion of all political prinoinles erbraced in our plateorm". (8) This cuestion caused consiterable discussion, some members opposing violently the abolition of partv secrecy.

(5) Louisville Daily Journal, 4pril 6, 1857

(6) Louisville Daily Journal, Narch 23, 1857

(7) Daily Democrat, June 6, 1857

(8) Ibid., June 10, 1857 
To meet a chaning political situation and to face local problems more adequately, the national convention resolvet that the varty in each state and territory be authorized to alopt such plan of organizationas tiey may think best suited to the views of the members of their anty in their several localities." "fter a "spirited and heated debate", (9) the national convention reaffirmed the platform of princioles laid hown by the 1856 convention. The same position on foreign influence was entertained, Mr. J. J. Crittenden, a convention speaker, mintainine that "there are parties in the country that derive their power from the foreinn vote, ant that is the most enormous view of the ruestion. That foreign vote has eiected every President sime the lavs of andrew Jackson". (10)

In the urust election in 1857 there ere tro imoortant offices to he filled, those of conoressman ant state treasurer. Hurphrey Narshall Wus the know-Nothing canditate Cor re-election to conoress an? he was opposed by Thomas Hoit. The office of state treasurer was sought by tames ti. Garrard, Democratic candidate, and Thomas I. Jones, Know-Nothing candinte.

Intimations thit the "hrethren shal] to better than in 1855 " caused the Democratic organ no little cocorn ant cal]ed ther to challenge tio knorNothing organ "to say distinctly if his party intents to suppress tho foreign vote th the ensuing election". (11) he cenocratic oross felt that the temper of the Know-Nothing party was such that the awful scenes of hurust 6,1855 might be repeated. (12) In this election the Democrats, who had for sometime been comparatively nsive at election time, were maring a real effort to win. In a speech, July 1, 185?, Thomas Holt, Cemocratic candidate said, "I

(9) Daily Democrat, June 4, 1357 .

(10) Ibid., June 5,1857

(1]) Louisville Laily Democrat, June 28, 1857

(12) Ihid., July I, 1857. 
again affirm most solemnly, temperately, and firmly, that we will on the first Monday in August cxorcise tha rights of suffrace conferred by the laws of the land and if we are driven from the polls it will be when every paving-stone in this city shall be watered by the blood of outraged freeman".(13) Another Democratic organ is quoted as saying "if we, as Democrats, are enlisted in performing our duty, as we heretofore were, our streets shall surpass the bloody carnare of "Tater $100 "$ ". (14)

The question of having a plice force adequate to deal with election disturbances came up again at this election. One Democratic orcan suggested extra policemen, "composed of an equal numier of respectablo citizens from each ward", to aid the regular police on electicn day. (15) The Know-Nothine press maintained that the regular police force was sufficient to maintain law and order and then accused the Democrats of wanting to withdraw the entire police force on election day "to leave their blood-thirsty bullies to regulate the election after their om pearliar fashion". (16) The Louisville Daily Courier wrote that the Daily Journal had clearly misinterpreted an article contained in the Courier, which read as follows:

"The Mayor should do one of two thins--wither appoint a sufficiont police force to keep peace at the polls or else withdraw all protection and let the voters take care of themselves." (I7)

The Wayor of Louisville, Mr. Pilcher, was asked specifically by the Democrats and he accordine to the Daily Democrat, "declines definitely to give us any police force at the polls such as suggested by the comnittee; and for the usual reason eiven by the or fan". (18)

(13) Quoted in the Louisville Daily Journal, July 3, 1857.

(14) Ibtid., July 13, 1857.

(15) Louisville Daily Denocrat, July 27, 1857

(16) Quoted in Louisville Daily Courier, July 3, 1857.

(17) Louisville Daily Courier, June 27, 1857 .

(18) Daily Democrat. July 29, 1857 , comnittee had called on the Mayor. and suggested the plan of having extra policemen as stated above. 
Mayor Pilcher issued a proclamation closing "houses of taverns and coffee houses and not to sell any spiritous liauors on election day, from the rising of the sun till the going down of the samen. (19)

With the increase in power of the Democratic party in Louisville the question of the eligibility of naturalized citizens was a mafor issue. The Denocratic organ contended that in case of doubt as to the eligibility of naturalized citizens the individual should be given the benefit of the doubt. of course, the Inow-liothings felt that the doubt should be "construed in favor of the country". The position of the know-iothings was that foreigners were not fit to exercise the rights of citizens until all the requirements had been net. (20)

The Attorney General, James Harlow, gave an opinion on this naturalization question, July 27, 1857:

1. Count, courts have no power to natiralize foroigners.

2. No records of naturalization from other states are valid unless "attested by the clork thereof, with the seal of the court annexed and certified by the Judge.."

3. A foreigner must reside in the state two years after Naturalization, that is as a citizen before he can vote and sixty days in the precinct as a citizen. (21)

The previous practice had been that foreigners who had fulfilled residence requirements could vote just as soon as the were naturalized. The Democrats refused to accept this opinion and urged that every election conducted according to Attorney General Harlow's opinion s'ould be contested. Commenting on the decision, the Louisville Daily Courier said, "He cannot make a naturalized citizen live two years in the state after naturalization before voting unless he nakes a native-born citizen reside the same length of time after he is twenty-one years of age before roting". (22)

(19) Ibid., August 1, 1857.

(20) Louisville Daily Journal, August 1, 1857.

(21) Louisville Daily Journa1, August 1, 1857

(22) Louisville $\overline{\text { Daily }}$ Courier, July 30, 1857. 
Actual disturbances on election day were few ihulah there was the usual disagreement between Democrats and know-ivothings over the extent of the violence. In the middle warce things went off quietly but in the first and eighth wards, both havine a huge German population, there were a number of disturbances. In the first ward the total vote was 1400 but only one-half of that was actually polled, (23) In the eighth ward "every dirty trick was resorted to by the know-Nothings to secure votors." A nunber of people were assaulted. (24) According to the Louisville Daily Journal "never was there a more peaceful election. the Sag Nichts made desperate effort, polling within 150 of their entire strangth; while more than a thousand American voters were left unpolled. The usual overwhelming American majority.....induced a carelessness much to be regretted". (25) "ith reference to the Democratic contention that nany Democratic voters had been intimidated, the journal stated that "the suppressed vote is nearly all American". (26)

In the city. Marshall polled 2,910 votes to 1,852 for Holt and Jones polled 2,882 votes to 1,794 for Garrard. (27) \& comparison between tine votes polled in November, 1856 and August, 1857, shows a f'alling off of votes.

$\begin{array}{ll}\text { November, } 1856 & \text { August, } 1857 \\ \text { Billmore, } 3,830 & \text { Nershal1 } 2,910 \\ \text { Buchanan, 2,014 } & \text { Holt, } 1,852\end{array}$

There was a falling off of the vote of about 1,096 votes: "of that 162 were from the side of Democracy, 920 from Americans". (28)

In Jefferson county the vote stood:

For Congress, 7th District For Treasurer Marshal1, 3,925 Jones 3,859 Folt, $2,828 \quad$ Garrard, 2,754

(23) Lovisville Daily Democrat, August 4, 1857

(24) Louisville Daily Tourier, July 30, 1857.

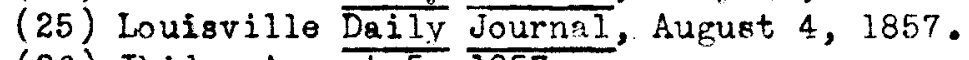

(26) Ibid., August 5, 1857.

(27) Ibid., August 4, 1857; and Louisville Daily Democrat August 4, 1857 .

(28) Louisville Daily Journal, August 5, 1857. 
For the state as a whole Garrard, Democratic candidate, was elected

state treasurer over Jones, know-Nothing candicate, by a vote of 65,590 to 53,476. Eight Democrats and two Know-Nothings were elected to Congress, sixtyone Democrats and thirty-nine know-iothings were elected to the fouse of Representatives, and thirteen Democrats and seven know-Nothings were elected to the Senate. the new Senate had twenty Know-ivothins and eifhteen Democrats. (29)

In the year 1858 there were four elections in Kentucky in which the citizens of Louisville took part. The most important election of that year was that of August 2, which was significant from one viewpoint, because the Democrats at that time roused themselves and greatly increased their local party machine.

In January, 1858, an election for Judge of the Seventh Judicial District was made necessary because of the resignation of Judge $\%$. F. Bullock. The Know-iNotrings put up Peter B. Muir for their candidate and the Democrats didn't select a candidate. They would likely have supported I. J. Throap but they learned that he was know-Nothing so that cost him Democratic support. (30) Mir was elocted by a majority of 1,717 votes. (31) According to a Democrat paper "he might have been defeated by Wir. Ihroap if the Democrats had not considered him(Throap) a know-Nothing". (32)

In the election for U. S. Senator, which took place January 8 , 1858, Lazarus $\%$. Powe11, Lemocrat and former governor of Kentucky was elected over Garret Davis, know-lothing candidate by a vote of 80 to 54 . (33)

Un Wednesday, January 7 , E. Benson was nominated for city marshall for the election, January 16, 1858. (34) The Democrats did not even bther to make nomination, thus making the election "one-sided and therefore of little interest". (35) In fact, so epathetic ras the Denocratic organization

(29) Collins, Vol. l, p 78 .

(30) Louisville Daily Journa 1, January 2, 1858; Louisville Daily Courier January $4, \overline{1858 .}$

(31) Louisville Daily Journal, January 4,1858

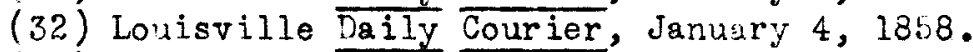

(33) Collins, History, p. 79.

(34) Louisville Daily Journal, January 7, 1858.

(35) Douisville Daily Courier, January $18,1858$. 
that some Democratic organs commended the candidacy of Mr. Benson. (36) Mr. Alex Gilmore, Independent, opposed Benson but he was beaten, Benson receiving a majority of 500 votes. (37)

Again in the municipal elections, April 3, the Democrats did not openly nominate candidates for city offices. A Democratic organ published a complete slate of candidates, running f'or office on a Citizens ilicket, and heing chosen as candidates for the respective offices "without regard to party." (38) The know-Nothing organization did not kindly accept the "bumble acknowledgment" by the Democrats that their party was in the rinority, for in the selection of a so-called Citizens Ticket, the Know-Nothings sensed a Democratic scheme to draw Know-Nothine votes. (39) In following this plan as they did in several election contests, the Dewocrats underestimated the importance of efficient local organization, wich they probaly had never had.

The election went of: comparatively quiet ly although the Democratic organ witnessed the usual outrages and the usual illegal voting. The total vote cast for City Councilmen, in argregate, was 2,181 for the Americans, and 937 for the vemocrats, a natiority of 1244. (40) In the Third ward the race was unusually close, Dr. wat Pyles being deceated by forty-eight votes. Fe was so sure that he had legally won that he threatened to contest the election, but did not. (41)

As stated above the August elections of 1857 marked the re-entrance of the Democrats into local politics. This election also signalled the end of the know-ilothing party becuse the results of the election so undeniably showed the great change taking place in political alignments. the know-iothing forces,

(36) Louisville Daily Democrat, January 7, 1858.

(37) Louisville Daily Courier, January 19, 1858.

(38) Ibid., farch 29, 1858 .

(39) Louisville Daily Journal, March 24, 1858 and April 3, 1858.

(40) Ibid., Apri15, 1858 (The Journal refers to "Democratic" candidates and not "citizens" candidates).

(41) Louisville Daily Courier, April 5, 1858. 
faced with the fact that in Louisville alone was there any strength in the Kentucky-Know-Nothing organization, watched the Democratic preparations unxiously. There were reports of Democratic happenings in Lodisville trat showed the "hands of the Democratic nanacers of "lashington" plainly visible. (42) In the various wards of the city the Democrats organized squads of one-hundred wen for each ward for the sole purpose of getting out a full Democratic vote.

Both parties were anxious for the election to be conducted peacefully. Inlike former elections these solicitations were more practical. For example, "officers of the election are equally divided between the two parties. (43) This provision met one of the main objections of the Democratic purty and was cortainly areat step forward in the peaceful conducting of elections. The Know-Nothing organ had maintained for some tine that the cause of the disturbance at the polls was due to the atternt of many foreigners to vote illegally. The Louistille Daily Courier, then, tied to impress upon the foreigner the importance of producing their certificates of naturalization at the polls "unless their qualification is known to one of the judges or the sheriff." (44) Another measure that nade for a more peaceful election was the provision for more polling places in sme of the wards: vamely, the first, second, and eighth wards each had no polling places. (45) Iha usual police protection was provided with the additional safeguard that three rilitary companies were stationed at the armory awaiting orders from the Mayor should there be any disturbance; "every necessary precaution" had been taken. Only in one instance was there any gloodshed in this election. In the sixth ward an altercation took place hetween a Ar. Standiford and Captain

(42) Jouisville Daily Journal, July 10, 1358.

(43) Louisville Daily curier, July $31,1858$.

(44) Ibid., July 20,1858. (quotation from Kevised statutes p. 286)

(45) Louisville Daily Journa 1, August 3 , 1858. (The First and ighth wards both had large German populations.) 
I. A. Rousseau on the stens of the courthouse. Both men vere wounded. The

cause of the troule wa "a personal matter" more then any political difference. At the first and socond wrd polls there were several "f'ist and skil encounters"; several foreigners in the cond ward wore beaten and driven away from the polls. Miat conflicts there were at the polls were caused by the democrats trying to cast illegal votes, according to the Louisville Daily Journal which stated," if this had not been done the public peace would doubtless have remained unbroken." (46) The Democrats claimed that up until nocn they were leading and that in the afterncon the Democlatic lead was overcome by fraud and voting Know-Nothing bullies.(47)

The results of the election in August, 1853, ir. Louisville are as follows:

\begin{tabular}{|c|c|c|}
\hline For & Know-Nothing & Denocratio \\
\hline Appellate jud gee & "hest, 3,654 & Tood 3,565 \\
\hline Appellate clerk & Netee 3,680 & Revill, 3,488 \\
\hline County judge & Thurstor 3,710 & Pyles 3,467 \\
\hline Sheriff & Magowan 3,846 & Ellis 3,342 \\
\hline County inilor & Thories 3,539 & Eatman 3,645 \\
\hline County attorney & Jones 3,505 & \\
\hline Coroner & Ducharain 3,611 & Forsythe 3,457 \\
\hline hssessor & Larrison 3,561 & \\
\hline Surve;or & Davis 3,429 & Kovb 3,573 \\
\hline
\end{tabular}

In Louisville Eatnan and Kobb, Democratic candidates, were elected. All other city officers elected were Kanv-Nottings. (18) In Jefferson County all the Democratic candiates were elected. (49) In the state Kevill, Democratic candidate for Appellate Clerk, defeated lickee 68 , 40 to 55,199 having a majority of 13,341 votes. Wood also defeated Judge Theat. (50)

The remocratic orkan took the election of huglust 2 , 1858 , to indicate that (40) Louisville Daily Journal, hugust $4,1858$. (47) Louisville Daily Courier, August 3, 1858. (48) Louisville Daily Journal, August $3,1858$.

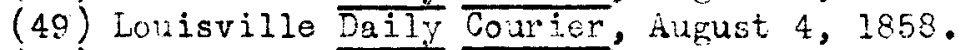
(50) Collins, istory, 
Humprey Marshall would be defeated as Know-Nothing candidate for Congress in 1859. According to the Democratic organ there had been a steady increase of Democratic strength. The following figures denonstrate this. (51)

$$
\begin{aligned}
& \text { August, 1857, election itolt Varshall } \\
& \text { Jefferson County } \quad 2,828 \quad 3,925 \\
& \text { Fenry County } \quad 953 \quad 663 \\
& \text { Olaham County } \quad 530 \quad 364 \\
& \text { Shelb County } \frac{668}{4,979} \quad \frac{1,133}{6,085} \\
& \frac{4,979}{1,106} \text { najority } \\
& \text { August, 1858, election } \\
& \text { Revill ckee } \\
& \text { Jefferson County } 3,493 \quad 3,732 \\
& \text { Eenry County } 1,047 \quad 631 \\
& \text { Oldham County } \quad 490 \quad 232 \\
& \text { Sheling County } \frac{712}{5,742} \quad \frac{1,095}{5,781} \\
& \underline{5,742} 39 \text { majority }
\end{aligned}
$$

One rather amsing incident resulted from this election. Batman, Democrat, had defeated Thomas, Know-Tothing cardidate and chairman of the KnowNothing State Executive Committee, in the race for county Jailer. Batman was refused a certificate of election by the election commissioners, two of whom, Joe Clements and Sam latlock, waro substitute commissioners. These two commissioners checked over the pollt books and declared invalid enough votes cast in favor of satrian to nake Thomas the Jiler.. Thomas at first said he would not take the office under the ciucumstances but he later reconsidered. Batman took legal action by petitioning Judge fluir to force the election commision to certify him (Batnar ) as Jailer. On Jonday, November 15, 1858, Judge inir denied Batman's petition and Thomas remained County Jailer. (52)

The election of Agust 2, 1858, "closed forever the hopes of the knowNothing party". In the United State Senate there were only two know-llothing

(51) Louisville Daily Courier, August 10, 1858.

(52) Louisville Daily Journal, August 5, 1858, August 6, 1858; Louisville Daily Courier, August 6, 1858 . 
Senators, Crittenden and sell of kentucky, and they were both docmed. (53)

$\because$

(53) Louisville Daily Courier, August 3, 1858. Lazarus Fowe11, Democrat, had been elected to the United State Senate in January, 1858, and the following year John $C$. breckenridge, Democrat, was elected to the United States Senate to take office in 1854. See Connelly Coulter, Vol. II. pp. 849,850 . 
CHAPTER VII

THE KNOH-MOTIING WRTY BECOEGS THF OPDOSTTION 
CUAPTER VII

\section{TAE KNOH-KHOTEING PART BECONES ThE OF_OSITION}

Proninent Kentucky historians regard the August election of 1858 as the time when the know-Nothing party ended.(1)

By the close of the year 1858 the main principles for which the KnowNothings had stood had been pushed as ide by the increasing concern over slavery. Fortunately for the know-Nothing leaders the Democratic party was splitting up. Buchanan"s administration had divided the Democratic party and the only chance for the know-Nothing organization was to get together the remains of their own party, the Mifs and the Old-Line Wigs and the anti-Lecompton Democrats into a united party of oppostion. In preparation for the election for governor in Kentucky in August, 1859, the Louisville Daily Journal issued an announcenent of an opposition convention to be held in Louisville, February 22; this announcement urged "harmony of action" free from " jealousy between Americans and Olc̀Line $\operatorname{thigs".~(4)~}$

Prior to the meeting of the opposition convention the Dernocrats of the state met in Frankfort January 8, to nominate candiates for the state election in August, 1859. This convention nominated Beriah Magoffin for governor; Lewis Bord for lieuténart-governor; Grant Greene for Auditor; James Garrard for Treasurer; and A. J. James for Attorney General. Division in the Kentucky Denocratic party was apparent since tle nominees were all supporters of Juchanan's administration and since none of them were 0ld-Line Thigs. (5) The Louisville Daily Democrat answered this charge $b$ saving the exclusion of old-Line thigs

(1) Connelly * Coulter,p. 851, "After the election 1858 the group feeling of the American party ended and the best that could be done was to form an "opposition party".

(2) Thodes, pp. 279-301.

(3) Thigs that had been co-operating with the Democrats.

(4) Louisville Daily Journal, October 23, 1858.

(5) Ibid., January 10, 1859. 
from state officies was "purely accidental". (6)

Reforring to the opposition convention to meet in Louisville, Feoruary 22, 1859, the Louisville Daily bourier suggested that the convention form a new politcal party called the "Free Nigger Party" --"those who will probably be in the meeting have abandoned the name Know-Nothing with which they started out in 1854 and "they now call themselves the 'opposition". (7)

The leaders of the opposition made a direct appeal to the Democratic opponents of Buchanan's administration by announcing the leading aim of the opposition party to be "the prostration of the iuchanan Democracy" (8) and "opposition to the corrupt administration of the General Government". (9) Aacording to the Journal the action of the Democratic State Convention made the "path of opposition" clear and led allopponents of the Buchanan administration to look for their only hope to the opposition convention in Louisville. (10)

One purpose in calling the opposition convention that attracted some men of $a l 1$ political creeds, even though they might be beaten by the lemocrats, was to denonstrate to the Northern Conservatives that there was a large body of Southern conservatives that had no sympathy with "hogus Democrats". The Kentucky opposition party followed the lead of a smilar group in Virginia in the hope that they could effect a union between northern and southern conservativies and "eleot a conservative and a national statesman to the presidency". (11)

The meeting of the opposition in Louisville in February was admittudly large; the Daily Denocrat wrote that there were about 1,500 delegates, all "showing a good deal of enthusiasm, especially on the nomination of Bell." (12)

(6) Louisville Daily Democrat, January 15, 1859.

(7) Louisville Daily Courier, February 14, 1859.

(8) Louisville Daily Journ $\overline{1}$, Jnnuary $18,1859$.

(a) Louisville Daily Journal, February 22, 1859.

(10) Ibid., January 19, 1859.

(11) Ibid., January 27, 1859.

(12) Louisville Daily Democrat, February 23, 1859. 
The resolution passed by this convention announced the opposition purposes to he to "prevent disunion". give veace on the slavery question, work for an economical and honest amministration of government, oppose the importation of "foreign felons".

The opposition nominated J. F. Bell for Governor; Alfred H. Allen for Lieutenant-Governor; James Har low, Attorney General; Thomas S. Page, Auditor; Daucherty Thite, Treasurer, (13)

The Know-Nothing organization in Louisville naintained its identity until after the opposition convention. In fact, the know-Nothings were considered as one powerful faction in the opposition convention, and there was nothing to indicate in the calling of the convention that the know-ivothing organization in Louisville ad ceased to function. The Know-Nothing ward organizations net as such during the nonth of January, 1859, in an endeavor to work up enthusiasm anong all nemers of Know-Nothing councils "and all those opposed to Democratic misrule". (14)

But with the meeting of the opposition convention in Louisvills, February, 1859, and the enthusiasm shown there, many were curious to know if the KnowNothings in Louisville could "all be transferred to the new party bodily." (15) Apparently so far, just four davs after the opening of the opposition convention, the Louisville vaily Journal carried an announcement of a local opposition meeting to be held February 26, 1859, for the purpose of noninating candidates for the Common Council and the Soard of Aldermen. (16)

Thus it was that by the time of the April election for muniolpal officers the Louisville Daily Journal, former violent, Know-iothing champion, was addressing its readers 28 "men of the opposition". (17)

(13) Louisville Daily Courier, Feoruary 23, 1859. See this paper for full statement of resolutions.

(14) Louisville Daily Journal, January 14, 1858.

(15) Louisville Daily Democrat, February 24, 1859.

(16) Louisville Daily Journal, February 25, 1859.

(17) Ibid., ApriI 1, 1859. 
CHAPTER VIII

CONCIUSION 
CONCLUS ION

One vel1-grounded principle of know-Nothingism, a real kentucky product, remained a factor in Kentucky politics; that was the traditional Kentucky stand for the Union. Alarm of the people of Kentucky for the welfare of the Union led to the calling of an oppci $\$$ in conventicy, February, 1860, in Frankfort for the purpose of nomingting a "union" man for president. This meoting, composed largely of $\mathrm{hig}$ igs and former know-Nothings refused to discuss the slavery question and called on the people to preserve the Union. (1) All of the delegates to this convention were not wigs or Know-Nothines, for in Kentucky foar for the Union caused many union meetines to/called "without distinction of party seeking to devise means to stay the course nf ovents". (2) The pebruary convention recommended $J$. $J$. Crittenden "to the favorable consiceration of a National Union Convantion as worthy of the exalted position of President".

As a result of the sentiment for tre union the Constitutional Inion Party was formed and its candidate, John Bell carried Kentucky in the Presidentiul election of 1860, polling 50,016 votes to 52,836 for beckenridge, 40,372 for Douglas, and 1,350 for Iincoli.

Thus in Kentucky, the impetus ziven o.t several years agitation in" ine preservation of the Union vas sufficiently strong to give that psrty (Constitutional Union) the victory in Kentucky when the rest of the country was hopelessly divided on the slavery question. To the very last the Unionists in Kentucky hat insisted or dodging the slavery issue.

(1) Fekister of Kentucky State jistorical Society, io. 67, f. 174.

(2) Connelly * Coulter, Vol. II, p. 852.

(3) Collins, Vol. I, p. 84.

(4) Ibid., p. 33. 
As is implied in the precesding paragraphs, the strong nativist movement in Kentucky vas partly responsible for keeping Kentucky in the Union when other southern states seceded. The period between the collapse of the Thig party and the election of 1860 had witnessed the growth of the Democratic party in Kentucky despite the fact that traditionally, the Democratic party rad been anathema to Kentuckians. But with the deatr of the "hig party, many whigs ware won over to the Democratic party because southern rights were more vitally important than abolitionism and partly because the Democratic party in Kentucky rodified its program sufficiently to win many whigs. The Denocrats even had an "internal improvement" wing in Kentucky! Because of the growing inportance of the Democratic party sentiment for the preservation of the Union might have died oxt had it not been for the rise of the know-iothing party. Reference had been made to the fact that the nativist movenent was not powerful enouch to sidetrack the slavery issue. This is more understandable in the South than in the North, for the South was in every way-socially, politically, and economically-interested in the preservation of the sistem of slavery. In the vorth, however, the slavery issue was primarily political and less inportant to the people of the North than tie presence of foreigners in the great American cities. Yet despite the long life of the know-Nothing party in the North, the slavery is sue caused the death of the nativist movenent. In dealing with the local aspects of the know-ivothing movement the question naturally arises, "who was responsible for the outraces attending the elections during the know-lothin donination?"--in a word, the know-lothings. This fact is difficult to deduce from to nowspapers because of the extrene partisanship that characterizer tein in tiat peicd. From the record one feels that the foreign and Catholic elements were alwrys on the defensive. Certainly the know-lothing organ, the ouisville Daily Journal was aggressive in its condemation of foreigners and Catholics. Then, the arguments of the know-Not inge were more inclined to appeal to the passions of the men rather than to tireir 
intellifence. The imponderables of Catholicism and the strangeness of foreigners were used by the know-Nothing leaders to arouse the fears of native Anericans that fundamental american principlos wore endangered. From another view, the secrecy attending the Know-Nothing organization increased the fcars of foreigners; a sort of vicious circlo prevailed.

For a period of at least four years the entire city governent of Louisville was in tho bands of the nativists. During that time violence at election time was the usial thing. Certainly the oity adnitictrations must bear some responsibility for the difficulties that arose almot every election day. Thus any aression that started from foreign somrces may have been provoked by the anfair adrinistation of government under the know-ivothings.

In addition to the nore or less tangible reasons for placing the responsibility for violence on the Know-Nothin:s, we have the evidence contained in histories. Historians deling with the know-Hothing novenent in a general way, place the blame for violence on the know-iothing party. (5) Ithis is also the verdict of contemporary historians.(6)

Several other facts about Know-ivothingism in Louisville mav be cited. an authority on anioipal eovernment states that in the decade before the Civil "ar "municipl government was in the formative stage. During the forties and fifties many changes were taking place". (7) In Louisville the presonce of the Krow-ivothing party produced a change in local party tactios; probably this was true of most of the cities of the Uississippi Valley, "With the advent of the Know-lNothings local party machines became better organized and began to nake

(5) Connelly o Coulter, History of Kentucky, p. 848 Vilson, Samuel, history of entucky, p. 226. footnotep.

(6) Memorial History of́touisville, Vol. I., . 123. Porrin, distory of Kentucky, p. 329.

(7) Munro, william ennett, Government of American Cities, Macifillan Company, New vorl, 1916, p. 11. Munro further states that at various points one encountered the beginning of a movement which gimed to make the myorality a semi-independent organ of city government-chosen directly by the people." 
nominations for city offices. For a time this practice gave the Know-Nothings advantages in municipal elections. (8) In a negative sense the rule, or misrule, of the Know-Nothing party in Louisville showed the need for better supervised elections, more polling places, and a more efficient police force.

The Know-Nothing movement called the attention of the American people to the presence of foreigners more forcibily than any previous nativist movement. This was probably due to the national character of the party. Whether or not the exclusion or expulsion for foreifners at the tine was important, certainly the presence of the foreiener in a rapidly crowing industrial society created certain political and social problems that demanded solution. By calling the attention of the people to the presence of the foreigner the process of assinilation was made more difficult. A problem was creatsd that had not existed before.

The secrecy of the know-Nothing party and its religious prejudices were "founded on principles contary to fundamental American institutions". (9) According to Macy the only real service of the know-Nothing party was the aid it gave to the disolution of the whig party and to the preparation of the way for the union of the Northern Whigs with the anti-slavery extension elements of the other parties into the Republican party. (10)

(8) See: Connelly * Coulter, History of Kentucky, Vol. II, p. 845 (quotation taken from Kentucky Yeoman, August 11, 1854.)

(9) Macy, Jesse, Political Parties in the United States, 1846-1861, Machillan \& Cornpany, New York, 1911, p. 180. (Wacy quotes ienry ward Beecher who referred to the Know-Nothing Councils as "the catacomis of freedom".)

(10) Grant, U. S., Memoirs, Vol. 1, p. 169 - "Most of my friends had known me as an officer in the army with "hig proclivities. The and besn on the same side and on the death of their party had becomo mambers of the Ailerican party. There was a lodge near me and I was invited to join it. I accepted the invitation was initiated and atiended a meting just one wook later; and never went to another afterwards".

(11) Ibid., p. 418 . 
The phenomenal rise to power of the know-jothing party is one of the most interesting incidents in American history. As an indication of the importance and potentialities of third party movements the career of the KnowNothing party may well serve as a lesson to people of our own day. 


\section{BISLIOGRAFHY}

\section{Primary Sources}

Abbott, Edith, $\frac{\text { Historical }}{\text { of Chicago }} \frac{\text { Aspects }}{\text { Prese, Chicago, Illinois, }} \frac{\text { Immigration, }}{\text { page }} \frac{\text { Socuments, University }}{504 .}$

DeBow, J. D. B., Seventh Census of the United States, 1850. Superintendent of United States Census, "Mshington, 1853.

Dictionary of American Biography, Volumes XII and XV.

Journal of the General Council of the City of Louisville, 1855 and 1856.

Journal of the House of Representatives of the State of Kentucky, December 5 , 1859; March 5, 1860; Kentucky Yoeman's Office, 1859.

Louisville Daily Courier, July 1854 - February, 1859.

Louisville Daily Democrat, May, 1854 - Viarch, 1859

Louisville Daily Journal, January 1850 - December, 1854 - April, 1859 .

Louisville Daily Times, January, 1856 - December 1856.

Louisville Evening Bulletin, July 1855 - December 1855.

Louisville Weekly Courier, January 1855 - December, 1855.

Louisville Weekly Journal, August 1854 - June 1854.

Register of Kentucky State Historical Society, no. 67.

\section{Secondary Sources}

Cole, A. C., Irrepressible Conflict, 1850-1870, Macilillan Company, 1934. The Whig Farty in the South, American Historical, 1913.

Collins, Richard H., History of Kentucky, Collins \& Company, 1882, Vol. I.

Connelly, T. E. and Coulter, E. M., History of Kentucky, American Historical Society, Chicago and New York, Vol. II.

Cotterill, R. S., The Old South, Arthur F. Clark \& Company, Glendale, CaIifornia, 1936. 
Editorial, harpers ifonthly Magazine, Vol. XI, September, 1855, p. 545.

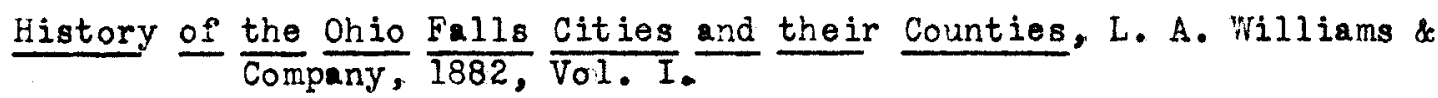

Jenkins, T. J., Know-Nothingism and its Destrayers, Catholic World, July,

Johnston, J. Stoddard, Memorial History of Louisville, from its first settlement to the year $\overline{189} \overline{6}$, American Biographical Fublishing Company.

Perrin, W. H., Kentucky, a History of the State, F. A. Battey \& Company, Louisvilie and Chicago, $188 \overline{8}$.

Rhodes, James Ford, History of the United States From the Compromise of 1850 to the First Restoration of $\mathrm{H}$ me $\mathrm{kul \theta}$ in the South in 1877 , Mac dilian Company, 1910 .

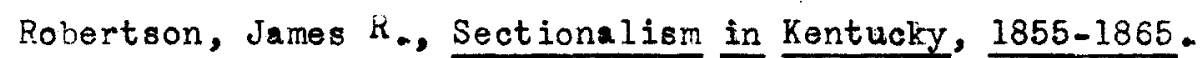
Mississippi valiey Historical Review, Vol. 4, pp. 48-63.

Scisco, L. D., Political Nativism in New York, Columbia University Press, New York, 1901, p. 66

Schmeckebier,. L. F., History $\frac{\text { of }}{\text { Hopkins }} \frac{\text { the Know-Nothing Farty in Maryland, Johns }}{1899, \text { p.9. }}$

Speed, James, James Speed, a Fersonality, Louisville, Worton, 1914, pp.

Sons of the Sires, a history of the rise, progress and destiny of the American Party, and its probably influence on the next Presidental election. Philadelphia, Lippincott, 1855.

Spencer, J. H., History of Kentucky Baptists, 1765-1885, n. p. Author, 1886.

Webb, Benjamin, Centenary of Catholicity in Kentucky, Louisville, Rogers, 1884.

Tebster, A. J., Louisville in the 1850"s, Filson Club Historical Quarterly, Vol. $4 .$, no. $3 ., \mathrm{p} \cdot 140$.

Willis, G. L., Kentucky Democracy, Dewocratic Historical Society, Louisville, 1935.

Wilson, Henry, Rise and F'all of the Slave Power in America, boston, Osgood, $\overline{1872,}$ p. $\overline{421 .}$

ilson, Samue 1, History of Kentucky, S. J. Clarke Company. Chicago and Louisvilie, 1928, Vol. II, p. 421. 